UNIVERSIDADE DE SÃO PAULO ESCOLA DE EDUCAÇÃO FÍSICA E ESPORTE

CARACTERÍSTICAS BIOMECÂNICAS DO SALTO E MUDANÇA DE DIREÇÃO EM MULHERES

PRATICANTES DE VOLEIBOL E BASQUETEBOL COM HISTÓRICO DE FRATURA POR ESTRESSE NA TÍBIA

Fábio Rodrigues José

SÃO PAULO

2011 


\title{
CARACTERÍSTICAS BIOMECÂNICAS DO SALTO E MUDANÇA DE DIREÇÃO EM MULHERES PRATICANTES DE VOLEIBOL E BASQUETEBOL COM HISTÓRICO DE FRATURA POR ESTRESSE NA TÍBIA
}

Fábio Rodrigues José

\begin{abstract}
Dissertação apresentada à Escola de Educação Física e Esporte da Universidade de São Paulo, como requisito parcial para obtenção do grau de Mestre em Educação Física.
\end{abstract}

ORIENTADOR: PROF. DR. JÚLIO CERCA SERRÃO 
Áliorzo a reproducsio e dwulgaclo lotal ou pareial deste trabaho. por qualquer meio convencional ou elotrónico, para fins de estudo e pesquisu. desde que criada a tonte

Jose Fabso Rodngues

Caracteristicas biomecânicas do salto e mudança de direçăo em mulheres praticantes de voleibol e basquetebol com histórico de fratura por estresse na tíbia / Fábio Rodrigues José. - Sāo Paulo: [s.n.], 2011

xvii, 78p

Dissertaçăo (Mestrado)- Escola de Educaçāo Fisica e Esporte da Universidade de São Paulo. 2011

\section{ORIENTADOR: PROF. DR. JÚLIO CERCA SERRÃO}

1. Fratura por estresse 2. Lesōes no Esporte 3. Biomecânica 4. Titulo

\section{VERSÃO CORRIGIDA}




\section{DEDICATÓRIA}

Dedico a presente dissertação aos meus pais, Lourenço José Filho e Guiomar Rodrigues José, pelo incentivo e todo esforço despendido em minha formação pessoal e profissional e aos eternos mestres que incentivaram, iniciaram e me acompanham em toda trajetória acadêmico-científica, Professor Doutor Júlio Cerca Serrão, Professor Mestre Alexandre Sabbag da Silva, Professor Mestre Edison Tresca e Professor Mestre Eduardo Günter Montero. A esses, minha eterna gratidão.

\section{AGRADECIMENTOS}

Dedico um agradecimento especial ao Prof ${ }^{\circledR}$ Dr. Júlio Cerca Serrão, por confiar em abrir-me as portas do laboratório, oportunizando assim meu ingresso no curso de mestrado. Por orientar-me em toda minha trajetória, acreditando e incentivando nas horas mais dificeis, ensinando nos momentos de dúvida e participando nos momentos de decisāo. Hoje tenho no professor o maior exemplo a seguir e na pessoa o orgulho de poder chamá-lo de irmāo.

Agradeço ao Prof $^{\circ}$ Alberto Carlos Amadio pelos seus ensinamentos através de palavras sábias, amigas e incentivadoras, por nunca medir esforços e dentro de seu escasso tempo sempre se dedicar a nos ajudar no que for preciso. Obrigado professor por ter criado os sólidos pilares dessa família e por nos servir de exemplo e inspiraçāo em todos os momentos.

Quando chegamos a um novo lugar, onde pouco conhecemos de sua rotina e nada conhecemos daqueles que frequentam, é a receptividade, apoio e amizade das pessoas que ali estão, que nos ajudam durante a fase de ambientizaçāo, nos encorajam a vencer as barreiras iniciais e nos dão força para ali continuar. Em minha chegada ao Laboratório de Biomecânica da Escola de Educação Física e Esporte da USP não foi diferente. O fato de hoje eu considerar-me um membro integrante dessa família, só foi possível pela receptividade e amizade de todos que conheci, que um dia o integraram ou que o integram até hoje. Sem essas pessoas e seu profundos ensinamentos, de nada valeria todo meu esforço para realização desse trabalho e aquisição de meu humilde conhecimento na área de Biomecânica. Agradeço de coração a essas pessoas: Ana Paula Bezerra, Ewertton de Souza Bezerra, Fernanda 
Acquesta, Germano Mongeli, Jaqueline Esterque, Katia Brandina, Luis Mochizuki, Sandro Barone e Yuji Yamaguti. No decorrer do tempo, novos amigos chegaram e contribuiram de forma nada diferente, merecendo assim os mesmos agradecimentos: Ana Carolina Menegatti, João Pedro Pinho, Juliana Roque de Souza, Mauro Cardaci, Rogério de Camargo Santos, Vanessa Russel e Vitor Henrique de Oliveira.

Agradeço ao meu grande amigo Prof ${ }^{\circ}$ Dr. Renato José Soares, pela preocupação e encorajamento no momento de meu ingresso no curso, sua ligação na data que precedia o processo seletivo de ingresso ao mestrado foi um dos pontos decisivos em minha aprovação

Agradeço ainda aos amigos Prof ${ }^{a}$ Ms. Alex Sandra Oliveira de Siqueira, Profa Dra. Carina Helena Wasem, Prof' Ms. Roberto Bianco e novamente ao Prof $^{\circ} \mathrm{Dr}$. Renato José Soares, por serem pessoas fundamentais em minha formaçāo. Agradeço também pela participação integral de todos no presente trabalho. Desde a idealização, desenvolvimento do protocolo de coleta, aprovação no comitê de ética e participação física nas coletas, até todo detalhamento final do documento. Vocês foram sensacionais.

Agradeço imensamente aos alunos de graduação Carolina Franco e Miguel Eustáquio por toda dedicaçāo e auxílio na coleta de dados

Agradeço aos novos amigos Daniel Lopes de Cápua e Bruno Mezencio que, surpreendentemente, nessa reta final, abriram mão de compromissos, inclusive familiares em datas festivas de final de ano, para trabalhar intensivamente na elaboração e processamento das rotinas matemáticas usadas no tratamento dos dados da presente dissertaçăo.

Agradeço aos amigos de FINASA-ESPORTES, Daniel Hideki Kan, Rodrigo Emanuel Sabbag e Heloisa Mansio, pela imensa contribuição na seleção, agendamento e organização dos sujeitos que constituíram a amostra.

Enfim, deixo aqui o registro de que todos aqui citados, hoje săo considerados membros de minha familia e expresso que não medirei esforços para que continuemos trabalhando juntos por toda nossa existência. 
Há homens que lutam um dia, e sâo bons;

Há outros que lutam um ano, e são melhores;

Há aqueles que lutam muitos anos, e são muito bons;

Porém há os que lutam toda a vida;

Estes sāo os imprescindiveis.

Bertold Brecht 


\section{RESUMO}

JOSE, F. R. Caracteristicas biomecânicas do salto e mudança de direção em mulheres praticantes de voleibol e basquetebol com histórico de fratura por estresse na tíbia. 2011. 99 f. Dissertação (Mestrado) - Faculdade de Educação Fisica e Esporte, Universidade de São Paulo, São Paulo, 2011.

Embora seja frequentemente incapacitante e apresente um alto indice de recidiva, condiçōes que ocasionam desde quadros de interrupção da atividade, até situações de acometimento total da estrutura cortical, os dados disponiveis na literatura especializada acerca da fratura por estresse são escassos. O objetivo deste trabalho foi analisar as caracteristicas biomecânicas de movimentos de locomoção de voluntários com históricos de fratura por estresse na tíbia. No presente estudo, foram analisadas 24 voluntárias: atletas

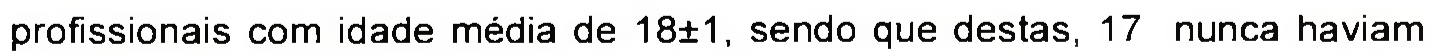
apresentado nenhum episódio de fratura por estresse tibial (grupo controle). $O$ grupo experimental $(n=7)$ foi composto por atletas profissionais (que haviam apresentado histórico de fraturas por estresse primária ou reincidente em algum momento de suas carreiras. O grupo controle $(n=17)$ também foi composto por atletas profissionais que no entanto não haviam apresentado qualquer tipo de lesão musculoesquelética nos últimos 6 meses. As voluntárias foram avaliadas em movimentos especificos das modalidades praticadas (basquete e voleibol): salto vertical, salto horizontal, e mudanças de direção. As voluntárias foram monitoradas bilateralmente por eletromiografia de superficie nos $\mathrm{mm}$. gastrocnêmio medial e tibial anterior onde foi avaliado RMS no janelamento de $50 \mathrm{~ms}$ pré e pós contato do sujeito com a plataforma de força nas condições de deslocamento antero-posterior, deslocamento lateral-medial, saltos horizontais e verticais, e pela plataforma de força piezoelétrica onde se avaliou a força pico, tempo de pico, gradiente de crescimento e impulso em $50 \mathrm{~ms}$ nos momentos de transição de massa para os deslocamentos, controle de carga para os saltos verticais e propulsāo e controle de carga para os saltos verticais. Os resultados mostram que apenas nas condiçōes de deslocamento ântero-posterior houveram diferenças estatisticamente significativas entre os grupos, sendo que nessa condição, o grupo experimental mostrou um tempo para pico de força diminuido $(0,20 \pm 0,090 \mathrm{~s}-15 \pm 0,09 \mathrm{~s})$ e um gradiente de 
crescimento aumentado $(12,63 \pm 10,04 \mathrm{~s}-20,7 \pm 18,31 \mathrm{~s})$ quando comparado ao grupo controle para as variáveis dinâmicas. Para a mesma condição, os parâmetros relacionados à ativação muscular do grupo experimental, apresentaram-se diferenciados em relação ao grupo controle. O músculo gastrocnêmio medial, no momento da transição do deslocamento anterior para posterior, apresentou uma atividade eletromiográfica maior no janelamento de $50 \mathrm{~ms}$ pré-contato com o solo $(1,19 \pm 0,84 \mathrm{~s}-1,43 \pm 0,62 \mathrm{~s})$. Os resultados obtidos evidenciam a existência de importantes alterações no acionamento muscular das voluntárias com histórico de fratura por estresse, alterações estas que podem explicar o comportamento dinâmico observado no grupo.

Palavras-chave: Fraturas por estresse, lesões esportivas, biomecânica. 


\section{ABSTRACT}

JOSE, F. R. Biomechanical characteristics of the jump and change direction in women's basketball and volleyball players with a history of stress fracture of the tibia. 2011. 99 f. Dissertação (Mestrado) - Faculdade de Educação Física e Esporte, Universidade de São Paulo, São Paulo, 2011.

Data available in literature about stress fractures are scarce, even though it is often disabling and presents a high recurrence rate. These conditions can cause disruption of activity and total involvement of bone cortical structure. The aim of this study was to analyze the biomechanical charateristics of locomotion of volunteers with history of tibial fracture caused by stress. In this study we analyzed 24 volunteers, professional athletes aged $18 \pm 1$. The experimental group was formed by 7 professional athletes who had previous primary or relapsed stress fractures. The control group was formed by 17 professional athletes who had not had any type of musculoskeletal injury in the last 6 months. The volunteers were evaluated in terms of specific movements of the practiced sport (basketball or volleyball) such as: vertical jump, horizontal jump, and changes of direction. The volunteers were monitored bilaterally by surface electromyography on the medial gastrocnemius and anterior tibial muscles. The electromyography rated RMS with $50 \mathrm{~ms}$ windows before and after the subject had contact with the force platform in conditions of anteriorposterior displacement, medial-lateral displacement and horizontal and-vertical jumps. The piezoelectric platform rated the peak force, time to peak, growth gradient and momentum in $50 \mathrm{~ms}$ during mass transition, load control, propulsion control and charge. The results showed statistically significant differences between groups under conditions of anteroposterior displacement. In this condition, the experimental group showed a decreased time to peak force $(0.20 \pm 0,09 \mathrm{~s}-0,15 \pm 0.09 \mathrm{~s})$ and an increased growth gradient (12.63 \pm 10.04 s to $20.7 \pm 18.31 \mathrm{~s}$ ) when compared to the control group. The parameters related to muscle activation in the same condition were different for the control and experimental groups. At the time of transition from anterior to posterior displacement, the medial gastrocnemius muscle's electromyographic activity showed a greater than $50 \mathrm{~ms}$ window prior to contact with the ground (1.19 \pm 
$0.84-1.43 \pm 0.62$ ). The results show that there were significant changes in muscle activation of the volunteers with history of stress fracture, these changes may explain the dynamic behavior observed in the group.

Keywords: Stress fractures, sports injuries and biomechanics. 


\section{Sumário}

1 INTRODUÇÃO

1

OBJETIVO

3

1.1 Objetivo geral ___

1.2 Objetivos especificos

2 REVISÃO DE LITERATURA__ 4

2.1 FRATURAS POR ESTRESSE:

2.1.1 Epidemiologia _________ 4

2.1.1 Fatores desencadeantes ________ 4

2.1.2 Classificação_____ 6

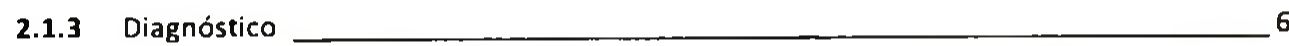

2.2 Instrumentos de Medição Usados na Avaliação Biomecânica ____ 15

2.1.4 Plataforma de Força de Reaçāo do Solo como método de investigação. _____ 15

2.1.5 Uso da Plataforma de Força de Reação do Solo como método de investigação nas fraturas por estresse. __________ 16

A 18

2.1.6 Eletromiografia como técnica de investigaçāo_______ 18

2.1.7 Tratamento matemático do sinal eletromiográfico. ___ 21

2.1.8 Eletromiografia como técnica de investigação na fratura por estresse __ 23

3 MATERIAIS E MÉTODOS___ 24

3.1 Amostra

3.2 Método de Diagnóstico____ 25

3.3 Procedimento experimental _______________ 25

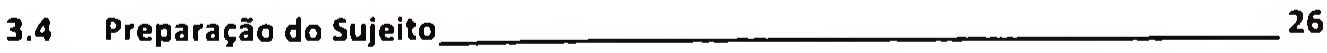

3.5 Protocolo Experimental ___ 27

3.6 Instrumentos de medição e parâmetros utilizados__ 29

3.6.1 Eletromiografia ___ 29

3.6.2 Plataforma de Força ____ 30

3.6.3 Procedimento para sincronização na aquisição simultânea dos dados. ___ 30 
3.7 Variáveis investigadas 30

3.7.1 Variáveis Cinemáticas 30

3.7.2 Variáveis Dinàmicas: Força de Reação do Solo 31

3.7.3 Variáveis Eletromiográficas 33

3.8 Critérios para a composição dos grupos 35

3.8.1 Procedimentos matemáticos 37

3.8.2 Tratamento estatístico dos dados 37

4 RESULTADOS 38

1.1 Variáveis dinâmicas: força de reação do solo 38

4.1 Variáveis eletromiográgicas 43

5 Discussão 53

6 Conclusão 58

7 Referências Bibliográficas 59

ANEXOS 70 


\section{LISTA DE FIGURAS}

Figura 1- llustração dos graus de Fratura por Estresse de acordo com as imagem apresentadas em fase tardia por um exame de Cintilografia Óssea Trifásica seguindo a classificação descrita por ZWAS(1987). 9

Figura 2: llustração do comportamento do tecido ósseo diante de diferentes ângulos de aplicação de carga. Sendo do ponto zero ao ponto de deflexão da curva - momento correspondente a zona elástica do tecido, o ponto de deflexão correspondente a transição entre a zona elástica e a zona plástica, do pondo de deflexāo ao final da reta o momento correspondente a zona plástica e o ponto final da reta correspondente ao momento de falha do tecido. Adaptado de NORDIN\&FRANKEL (2003). 10

Figura 3- Caracterização do fator de proteção muscular ao tecido ósseo. Adaptado de NORDIN \& FRANKEL (2003). 12

Figura 4 llustração de um Strain-Gauged Staples (SGS) $30^{\circ} \mathrm{em}$ padrão de roseta - grampos para aferir tração interna - 3M Health Care, St Paul, Minnesota).

Figura 5- llustração da fixação das SGS na tibia de soldados para o monitoramento das forças internas no tecido ósseo durante diferentes condiçōes de fadiga.

Figura 6- Eletrodos comumente utilizados na captação do sinal eletromiográfico. Eletrodo Ativo (A), Eletrodo Passivo (B), Eletrodo Intramuscular de fio (C) e Eletrodo Intramuscular de agulha (D).... 20

Figura7: Fluxograma que ilustra as etapas do procedimento experimental.. 26

Figura 8- llustração das variáveis cinéticas mensuradas na condiçāo de saltos horizontais (ataque e bandeja).

Figura 9- llustração das variáveis cinéticas mensuradas na condição de saltos verticais (vertical, bloqueio e bandeja) no momento de impulso. 32

Figura 10 - llustraçăo das variáveis cinéticas mensuradas na condiçăo de saltos horizontais (ataque e bandeja) no momento de aterrissagem. 33

Figura 11: llustração dos parâmetros utilizados para determinaçăo da intensidade da atividade muscular RMS pré e pós-contato nas condições $A$ deslocamentos anterior e lateral, B - saltos vertical, bloqueio e rebote e C - saltos 
horizontais (ataque e bandeja). .35

Figura 12- Média e desvio padrảo do tempo para o pico relacionado à componente vertical da Força de Reaçăo do Solo para os grupos controle e com histórico de Fratura por Estresse (FE) na condição de deslocamento anterior. Onde $\left(^{*}\right)$ indica diferença significativa $(p \geq 0,05)$ entre os grupos estudados. 39

Figura 13- Média e desvio padrāo do GC relacionados à componente vertical da Força de Reaçăo do Solo para os grupos controle e com histórico de Fratura por Estresse (FE) na condiçăo de deslocamento anterior. Onde (") indica diferença significativa $(p \geq 0,05)$ entre os grupos estudados. 39

Figura 14- Média e desvio padrão do Impulso aos $50 \mathrm{~ms}$ relacionados à Força de Reação do Solo para os grupo controle e com histórico de Fratura por Estresse na condiçảo de deslocamento lateral. Onde (") indica diferença significativa $(p \geq 0,05)$ entre os grupos estudados 40

Figura 15- Média e desvio padrão do tempo para pico relacionados à Força de Reaçăo do Solo para os grupo controle e com histórico de Fratura por Estresse na condiçăo de deslocamento lateral. Onde $\left(^{*}\right)$ indica diferença significativa $(p \geq 0,05)$ entre os grupos estudados

Figura 16- Média e desvio padrão do RMS (u.a.) para o músculos Gastrocnêmio Medial (GM) em 50ms pré-contato para o grupo controle e o grupo com histórico de Fratura por Estresse na condição de deslocamento anterior. Onde $\left(^{*}\right)$ indica diferença significativa $(p \geq 0,05)$ entre os grupos estudados. 44

Figura17- Média e desvio padrāo do RMS (u.a.) para o músculo Tibial Anterior (TA) em 50ms pós contato para o grupo controle e o grupo com histórico de Fratura por Estresse na condiçăo de ataque ou bandeja. Onde (*) indica diferença significativa $(p \geq 0,05)$ entre os grupos estudados. 46

Figura 18- Média e desvio padrão do RMS (u.a.) para o músculo Tibial Anterior (TA) em $50 \mathrm{~ms}$ pré-contato da fase de propulsão para o grupo controle e o grupo com histórico de Fratura por Estresse na condição de bloqueio/rebote. Onde $\left({ }^{\star}\right)$ indica diferença significativa $(p \geq 0,05)$ entre os grupos estudados

Figura19- Média e desvio padrão do RMS (u.a.) para o músculo Tibial Anterior (TA) no momento $50 \mathrm{~ms}$ pré-contato de propulsăo para o grupo controle e o grupo com histórico de Fratura por Estresse na condiçăo de salto vertical. Onde (") indica diferença significativa $(p \geq 0,05)$ entre os grupos estudados. 48

Figura 20- Média e desvio padrăo do RMS (u.a.) para o músculo Tibial 
Anterior (TA) no momento $50 \mathrm{~ms}$ pós-contato de propulsão para o grupo controle e o grupo com histórico de Fratura por Estresse na condição de salto vertical. Onde (") indica diferença significativa $(p \geq 0,05)$ entre os grupos estudados. 49

Figura 21- Média e desvio padrăo do RMS (u.a.) para o músculo Tibial Anterior (TA) no momento $50 \mathrm{~ms}$ pré-contato de aterrissagemo para o grupo controle e o grupo com histórico de Fratura por Estresse na condição de salto vertical. Onde $\left(^{*}\right)$ indica diferença significativa $(p \geq 0,05)$ entre os grupos estudados. 50

Figura22- Média e desvio padrăo do RMS (u.a.) para o músculo Tibial Anterior (TA) no momento $50 \mathrm{~ms}$ pós-contato de aterrissagem para o grupo controle e o grupo com histórico de Fratura por Estresse na condiçāo de salto vertical. Onde (*) indica diferença significativa $(p \geq 0,05)$ entre os grupos estudados.

Figura 23- Média e desvio padrāo do RMS (u.a.) para o músculo Gastrocnèmio medial (GM) no momento $50 \mathrm{~ms}$ pós-contato de aterrissagem para o grupo controle e o grupo com histórico de Fratura por Estresse na condição de salto vertical. Onde $\left(^{*}\right)$ indica diferença significativa $(p \geq 0,05)$ entre os grupos estudados.52 


\section{LISTA DE TABELAS}

Tabela 1 Conclusão de autores quanto as diferenças encontradas nas variáveis de FRS entre grupos de corredores que apresentaram fraturas por estresse quando comparados a um grupo controle (adaptado de ZADPOOR \& NIKOOYAN, 2011)

Tabela 2 - Média e desvio padrão de parâmetros relacionados à componente vertical da Força de Reaçăo do Solo para os grupo controle e com histórico de Fratura por Estresse (FE) na condição de deslocamento anterior. Onde (*) indica diferença significativa $(p \geq 0,05)$ entre os grupos estudados. 38

Tabela 3 - Média e desvio padrāo de parâmetros relacionados à Força de Reação do Solo para os grupo controle e com histórico de Fratura por Estresse na condição de deslocamento lateral. Onde $\left(^{*}\right)$ indica diferença significativa $(p \geq 0,05)$ entre os grupos estudados

Tabela 4- Média e desvio padrāo de parâmetros relacionados à Força de Reação do Solo para os grupos controle e com histórico de Fratura por Estresse nos saltos especificos (bandeja e ataque) para cada uma das modalidades. Onde (") indica diferença significativa $(p \geq 0,05)$ entre os grupos estudados.

Tabela 5 - Média e desvio padrão de parâmetros relacionados à Força de Reaçăo do Solo para os grupo controle e com histórico de Fratura por Estresse nos saltos especificos predominantemente verticais (bloqueio ou rebote). Onde (") indica diferença significativa $(p \geq 0,05)$ entre os grupos estudados

Tabela 6 Média e desvio padrão de parâmetros relacionados à Força de Reação do Solo para os grupo controle e com histórico de Fratura por Estresse na condição de salto vertical. Onde $\left(^{*}\right)$ indica diferença significativa $(p \geq 0,05)$ entre os grupos estudados

Tabela 7- Média e desvio padrão do RMS (u.a.) para os músculos Gastrocnemio Medial (GM) e Tibial anterior (TA) para o grupo controle e o grupo com histórico de Fratura por Estresse na condiçăo de deslocamento anterior. Onde $\left(^{*}\right)$ indica diferença significativa $(p \geq 0,05)$ entre os grupos estudados.

Tabela 8 - Média e desvio padrão do RMS (u.a.) para os músculos Gastrocnemio Medial (GM) e Tibial Anterior (TA) para o grupo controle e o grupo com histórico de Fratura por Estresse na condiçăo de deslocamento lateral. Onde (") 
indica diferença significativa $(p \geq 0,05)$ entre os grupos estudados. .45

Tabela 9- Média e desvio padrăo do RMS (u.a.) para os músculos Gastrocnemio Medial (GM) e Tibial Anterior (TA) para o grupo controle e o grupo com histórico de Fratura por Estresse na condição de ataque ou bandeja. Onde (") indica diferença significativa $(p \geq 0,05)$ entre os grupos estudados. 45

Tabela 10 - Média e desvio padrăo do RMS (u.a.) para os músculos Gastrocnemio Medial (GM) e Tibial Anterior (TA) para o grupo controle e $\circ$ grupo com histórico de Fratura por Estresse na condição de bloqueio/rebote. Onde (") indica diferença significativa $(p \geq 0,05)$ entre os grupos estudados 46

Tabela 11- Média e desvio padrão do RMS (u.a.) para os músculos Gastrocnemio Medial (GM) e Tibial Anterior (TA) para o grupo controle e o grupo com histórico de Fratura por Estresse na condiçăo de salto vertical. Onde (") indica diferença significativa $(p \geq 0,05)$ entre os grupos estudados 


\section{INTRODUÇÃo}

Uma fratura por estresse consiste no surgimento de fissuras microscópicas nos ossos, resultantes de uma falta de adaptação as cargas mecânicas geradas pelo movimento humano (DEVAS, 1975; GREANEY et al.1983; RUBIN et. al,1984) podendo variar, conforme o grau, em dimensão, extensão ou concentração de traçador de metilenodifosfonato (contraste aplicado de forma endovenosa em exames de Cintilografia Óssea) no ponto de lesão (ZWAS; ELKANOVITCH, FRANK, 1987).

Alèm de freqüente, o quadro de fratura de estresse é altamente incapacitante, podendo afastar o individuo por longo periodo de suas atividades, tornado-se assim um problema crônico (BARFIELD et. al, 2005).

Descrita clinicamente pela primeira vez em 1855 por Breithaupt, cirurgião militar alemāo, as fraturas por estresse tiveram seu primeiro registro em atletas em 1958 através da correlação clinico-radiográfica. A descrição em militares, fez com que os casos fossem inicialmente tratados na literatura como "fraturas da marcha". Embora historicamente tenham sido muito associadas ao treinamento militar, as fraturas por estresse estão intimamente relacionadas à prática esportiva competitiva.

Quando expressa em percentagem de todas as lesōes, as fraturas por estresse correspondem de $0,5 \%$ a $20 \%$ de todas as lesões sofridas pelos atletas (WARDEN et. al, 2006). Embora as fraturas de estresse tenham sido descritas em quase todos os ossos do corpo humano, elas são mais comuns nos membros inferiores, sendo as fraturas de membros superiores relacionadas a tração muscular, como o caso de fraturas de costelas em golfistas e remadores.

São muitos os agentes etiológicos capazes de conduzir as fraturas por estresse. Para COHEN \& ABDALLA (2003) os fatores de risco decorrem de aspectos como: idade, raça, nivel de atividade e de condicionamento físico, distúrbios hormonais, desequilibrios alimentares. Sugerem ainda os autores que alguns fatores antropométricos como a assimetria de membros, a anteversão femoral aumentada, a diminuição na largura da tíbia, o valgismo excessivo dos joelhos, e pronação dos pés também podem determinar o surgimento destas fraturas. 
ROMANI (2002) observou que o aumento de cargas de estresse pode provocar fraqueza óssea e uma maior susceptibilidade para ocorrer fraturas por estresse. As fraturas por estresse sảo mais comuns quando os ossos são repetitivamente carregados acima de um determinado ponto inicial de compressão ou tração (YOSHIKAWA et.al., 1994). Tais estiramentos ocorrem nos ossos em resposta aos ciclos repetitivo das cargas, quando a habilidade do corpo para atenuar as forças externas encontra-se diminuida (MIZRAHI, 2000).

Apesar de se tratar de uma lesão condicionada, dentre outros fatores, por condições biomecànicas adversas, os dados disponiveis sobre o assunto săo escassos. Em especial, muito pouco se sabe acerca das características biomecânicas dos movimentos daqueles atletas com histórico de fratura por estresse ou ainda se essas possiveis alteraçōes seriam causa o consequência da lesăo. Sendo assim, a investigaçảo das caracteristicas biomecânicas de um atleta com histórico de distúrbio ósseo relacionado a prática esportiva, pode ser mais um fator a contribuir para um melhor conhecimento das causas ou efeitos do problema, podendo assim, auxiliar futuramente em novas técnicas de tratamento, parâmetros para o acompanhamento da melhora de atletas acometidos por esta lesăo e elaboraçāo de programas preventivos e estratégias de individualização do treinamento. 
OBJETIVO

1.1

Objetivo geral

Buscando subsidios para o melhor entendimento de possiveis alteraçōes biomecânicas em atletas que já apresentaram algum grau de lesōes ósseas relacionadas a prática esportiva, o presente estudo tem como propósito determinar as caracteristicas biomecânicas dos saltos e mudanças bruscas de direção em atletas saltadoras com histórico de fratura por estresse na tíbia

\section{$1.2 \quad$ Objetivos especificos}

a) Analisar as características dinâmicas e eletromiográficas das condiçōes salto vertical, salto horizontal e mudanças de direção em atletas saltadores de alto rendimento, praticantes das modalidades voleibol e basquetebol, que em algum momento da carreira apresentaram algum episódio de lesão óssea atraumática primária ou reicidivante em grau I e/ou II :

b) Identificar, a partir da comparação com o grupo controle, a possível existência de agentes de natureza biomecânica que possam ser caracterizados como possiveis causadores de uma fratura por estresse. 


\section{REVISĀO DE LITERATURA}

\subsection{FRATURAS POR ESTRESSE:}

\subsubsection{Epidemiologia}

MILGROM et.al. (2006) cita a fratura por estresse como uma patologia musculoesquelética comum que afeta um grande número de atletas.

Apesar de sua incidência na populaçāo em geral ser inferior a $1 \%$, em corredores pode chegar a 15\%. Em uma revisāo de 320 atletas com fraturas por estresse, a tíbia foi o osso mais comumente envolvidos $(49,1 \%)$, seguido do tarso $(25,3 \%)$ e dos metatarsos $(8,8 \%)$. Dos casos documentados, $16,6 \%$ eram bilaterais e o gênero mais atingido foi o feminino. Embora descritas em quase todos os ossos do corpo humano, sāo mais comuns nos membros inferiores (MATHESON, 1987). Segundo FREDERICSON et. al. (2006), as fraturas por estresse correspondem a $20 \%$ de todas as lesōes clínicas da medicina desportiva.

Quanto ao prognóstico, as Fraturas de estresse podem ser divididas em dois grupo, sendo o primeiro considerado de baixo risco (prognóstico favorável quando tratadas com restriçāo de atividade) e o segundo considerado como de alto risco (uniāo retardada, especialmente se o diagnóstico for tardio e o tratamento inadequado) (BODEN \& OSBAHR, 2000; BODEN et. al, 2001).

Quando se relaciona incidência das fraturas de estresse a regiāo anatômica, $50 \%$ das fraturas por estresse de corredores foram relatadas na região média e terço distal da Tíbia (MIZRAHI, 2000). Embora raramente citada em esportes coletivos, existe a evidència de que em atletas de Voleibol e Basquetebol sustentase a predominância de fraturas por estresse na diäise tibial (IWAMOTO \&TAKEDA, 2003).

\subsubsection{Fatores desencadeantes}

Embora na literatura muitos fatores estejam relacionados ao surgimento de uma fratura por estresse, devemos atentar ao fato de que muitos deles são baseados em evidências clínicas e não em dados cientificos.

Para TIETZ (1987) a etiologia de uma fratura por estresse é pautada em duas teorias: a primeira afirma que a musculatura enfraquecida permite que as forças impostas ao aparelho locomotor sejam distribuidas a determinados pontos dos 
ossos, o que explica as fraturas por estresse de membros inferiores; a segunda diz que a traçăo muscular repetitiva pode gerar forças capazes de desencadear uma fratura por estresse, o que explica o acometimento de membros superiores.

Uma relação ao estreitamento tibial e massa muscular tem mostrado ser um fator predisponente do risco da fratura por estresse e fragilidade óssea em recrutas militares e atletas do sexo masculino. Esta correlação sugere que a morfologia óssea poderia ser considerada como fator predisponente de fratura por estresse, as propriedades mecânicas da cortical óssea variam em funçăo do tamanho do osso, além disso, condiçōes de sobrecarga e variação na qualidade óssea podem ser um fator contribuinte para o aumento do risco de fraturas por estresse (TOMMAZINI, 2005).

Segundo KORPELAINEN (2001), atletas do sexo masculino e feminino com histórico de múltiplas fraturas por estresse apresentar em seu estudo pés cavos, tornozelos excessivamente varos e discrepância de membros inferiores.

Em mulheres, fatores como tríade da mulher atleta que se caracteriza pela presença de distürbios dietéticos, amenorréia e osteoporose, distúrbios menstruais (oligomenorréia, amenorréia) caracterizado por um estado de hipoestrogenismo podem ocasionar fraturas por estresse (COHEN.\& ABDALLA, 2003).

Dentro das caracteristicas da locomoçăo, é de extrema importância a observação de parâmetros dinâmicos. pois esses possuem relação direta com a capacidade de controle de carga do individuo.

Durante a locomoçāo humana, o primeiro pico da FRS representa o momento crítico da aplicação desta força. Sua caracteristica mais expressiva è o rápido crescimento em um pequeno intervalo de tempo. O tempo necessário para a resposta ativa dos músculos é geralmente maior do que o tempo necessário para a força atingir o seu pico máximo, fato esse que pode fazer com que a força seja transmitida diretamente para o tecido ósseo (SERRAO, 1999). Na corrida, por exemplo, o primeiro pico é alcançado em aproximadamente $30 \mathrm{~ms}$ (CAVANAGH \& LAFORTUNE, 1980; MILLER, 1990), enquanto a resposta muscular dos membros inferiores não ocorre antes de 40 ms (WINTER \& BISHOP, 1992). 


\subsubsection{Classificação}

Embora em tempos atuais o termo fratura por estresse seja comumente usado para mencionar fraturas ósseas por esforço repetitivo, a fratura cortical ocorre apenas em um estado avançado da doença, sendo caracterizado o estado inicial apenas por uma reaçāo osteblástica relacionada a perturbaçāo mecânica. A não interrupçāo da perturbaçăo associada a incapacidade de adaptaçāo óssea as cargas empregadas, gera um quadro de microfraturas que, se agravadas, podem evoluir para uma fratura completa, aumentando assim a deficiência óssea (ZWAS, 1987).

$\mathrm{Na}$ tentativa de melhor classificar uma Fratura por Estresse em seus diferentes estágios de evoluçāo, outros termos foram empregados. Vulgarmente chamada de "Canelite", os termos Tibialgia, Periostite ou ainda Sindrome do Estresse Tibial Medial foram assim empregados para caracterizar reaçōes osteoplásticas e/ou inflamatórias da fáscia na borda póstero-medial da tibia caracterizadas por irritaçăo periosteal, possivelmente causada pela ruptura das fibras de Sharpey, entre o tendāo do músculo solear e o osso (GALBRAITH, 2009). Por sua longa inserção na regiāo da Tíbia, o músculo solear é considerado um dos principais causadores da Síndrome do Estresse Tibial Medial pela traçāo repetitiva e a consequẽnte periostite. Porém, estudos mostraram que o córtex tibial já apresenta sinais de osteopenia em estágios iniciais da doença e que a medula óssea também já apresenta sinais de acometimento (MOEN et. al; 2010)

\subsubsection{Diagnóstico}

Aos primeiros sinais que evidenciem uma suspeita clinica de Fratura por Estresse, manuseios apropriados para esta lesāo devem ser realizados imediatamente. Seu diagnóstico se faz baseado nos preceitos clássicos empregados na ortopedia: história (dor insidiosa e progressivamente limitante relacionado a atividade esportiva), exame físico geral e ortopédico ( $A$ fratura por estresse de tíbia pode causar dor local e edema, geralmente resultando em um afastamento temporário dos treinos e diminuiçảo do rendimento (EKENMAM et. al; 2000)), exames laboratoriais e diagnósticos por imagem. Sintomas geralmente surgem cerca de 4 a 5 semanas após a modificaçảo do treinamento, o diagnóstico é essencialmente clínico, mas as modalidades de imagem, como radiografia simples, 
cintilografia, tomografia computadorizada e ressonància magnética podem servir como método complementar para a confirmaçăo do diagnóstico, ou ainda para a classificaçăo do grau de acometimento ósseo pela fratura. Deve-se evidenciar a importância de uma análise comparativa dos diferentes métodos de imagem, sendo necessário uma coerente escolha, combinação ou năo e sequência correta de solicitação dos mesmos (BODEN \& OSBAHR, 2000; ROMANI, 2002). Em atletas de alto rendimento, sobretudo em nivel de competição, os exames de imagem são adotados com o intuito de reconhecer de forma correto e precoce a graduação da patologia. O presente fato é de fundamental importância para definição da conduta terapêutica, controle evolutivo da lesāo e parâmetro de liberação ao retorno da prática esportiva competitiva (GARDNER, 1988).

Na radiografia $(R X)$ simples a fratura de estresse aparece como uma linha de fratura radio luzente, focal esclerose devido à formação de calo endósteo, reação periosteal ou como um calo external. É um exame simples, de baixo custo e de fácil acesso, porém é necessário que haja troca na densidade óssea para que os sinais típicos de fratura de estresse sejam evidenciados. Por isso, em fases iniciais, em torno de $80 \%$ das fraturas de estresse năo săo evidentes com esse método complementar, sendo que entre uma e três semanas a sensibilidade aumenta para em torno de 50\% (KEMPFER, 2004).

GAETA (2005), em um estudo prospectivo, comparou o uso tomografia computadorizada (TC), da ressonância nuclear magnética (RNM) e da Cintilografia Óssea Trifásica em atletas com suspeita clinica de lesão por estresse precoce tibial. Um total de 42 pacientes que apresentavam dor tibial devido a lesāo por estresse, foram precocemente avaliados e submetidos a uma radiografia inicial que era negativa para a lesão. RNM, TC e Cintilografia Óssea foram realizadas em todos os pacientes com 1 mês a partir dos inicio dos sintomas. Dez sujeitos voluntários serviram como grupo controle. Pode-se avaliar a localização da lesão tibial, tipo de alteração óssea, presença de edema ósseo e periostite. A partir desta pesquisa os autores puderam concluir que a RNM é melhor do que a TC na avaliação de pacientes com suspeita de lesão por estresse precoce. Nos casos onde os achados de RNM são negativos a Cintilografía Óssea Trifásica pode ser uma boa opção para localizar a lesão por fadiga cortical óssea

AOKI et al, (2004) realizaram um estudo para determinar se a Fratura por Estresse e a Síndrome do Estresse Tibial Medial poderiam ser avaliadas por RNM 
em fases iniciais. Foram avaliados através de RNM e RX 20 atletas que apresentavam dor na parte médio distal da tíbia durante ou após atividades esportivas. Com o uso da RNM as Fraturas por Estresse foram diagnosticadas enquanto a radiografia mostrou periostite local ou linha de fratura e a Sindrome do Estresse Tibial Medial foi diagnosticada apenas com o uso da RNM. Os resultados mostraram que a RNM é a ferramenta usada geralmente para distinguir a Fratura por Estresse da Sindrome do Estresse Tibial Medial.

A Cintilografia Óssea Trifásica é realizada através da injeção endovenosa de um traçador radioativo ou radiofármaco. O traçador comumente utilizado é denominado metilenodifosfonato (MDP) e é marcado com tecnécio-99m(MDP_ ${ }^{99 m} \mathrm{Tc}$ ). Um estudo trifásico consiste em uma Cintilografia Óssea realizada em três fases. A primeira fase é denominada fase de fluxo sanguíneo (ou fase angiográfica). O paciente é posicionado com região de interesse sob o detector. O MDP- ${ }^{99 m}$ Tc é injetado em bolus em uma veia periférica e são adquiridas imagens da regiăo a cada 2 segundos durante 1 minuto. A segunda fase é denominada fase de equilibrio (ou fase de permeabilidade capilar) e inicia-se 5 minutos após a injeção do MDP. ${ }^{99 m}$ Tc. A terceira fase é denominada fase tardia e inicia-se após 3 horas. São realizadas imagens de todo o esqueleto nas projeçōes anterior e posterior. O MDP_99m Tc já está concentrado no osso.

A cintilografia óssea trifásica além de diagnosticar a fratura de estresse pode determinar em que estágio se encontra a lesāo. Segundo ZWAS (1987), uma Fratura por estresse em um exame de Cintilografia Óssea pode ser mensurada baseandose na imagem da dimensão e extensāo do foco de fratura e na quantidade de concentração de marcador radioativo local, podendo ser classificada em quatro graus de resposta:

- Grau I: pequena extensão da lesão, com dimensão da imagem mal definida e com leve acúmulo do traçador radiofármaco na região cortical.

- Grau II: maior extensão da lesão, com dimensão da imagem bem definida e aumento de acúmulo do traçador radiofármaco na região cortical.

- Grau III: imagem fusiforme com acúmulo do traçador radiofármaco altamente aumentada na regiăo córtico-medular.

- Grau IV: imagem fusiforme e extensa, com acúmulo do traçador 
radiofármaco altamente aumentada na regiảo transcortico-medular.

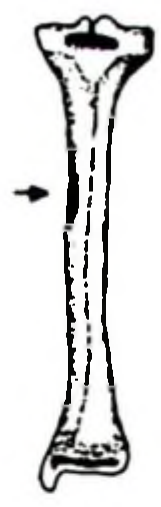

1

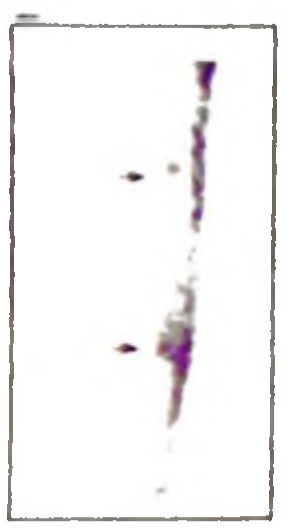

1

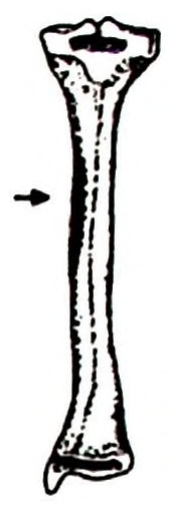

II

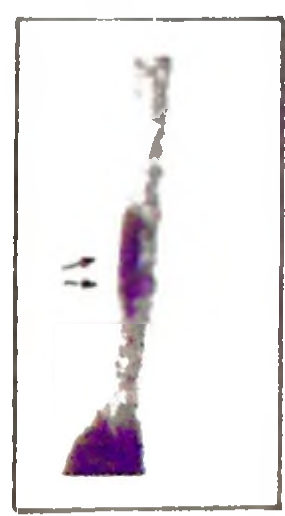

11

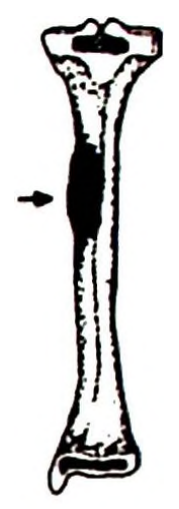

III

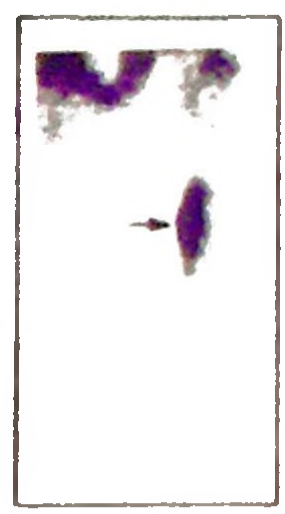

II!

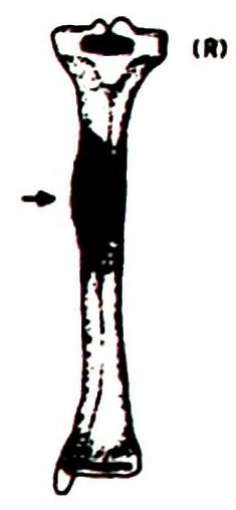

IV

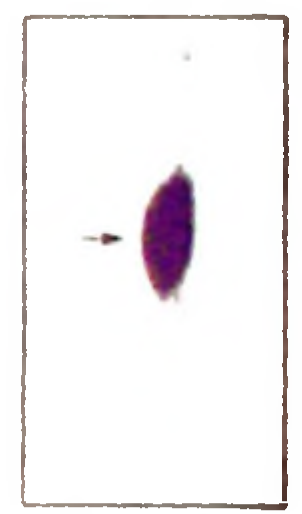

IV

Figura 1- llustração dos graus de Fratura por Estresse de acordo com as imagem apresentadas em fase tardia por um exame de Cintilografia Óssea Trifásica seguindo a classificaçăo descrita por ZWAS(1987).

\subsubsection{Propriedades Biomecânicas da Fratura por Estresse}

Para um melhor entendimento de como pode ser desencadeado um processo de fratura por estresse, se faz necessária uma descriçăo das características do tecido ósseo, seu comportamento quando exposto a carga, estratégias usadas pelo aparelho locomotor para proteger esse tecido e os fatores que podem desencadear alteraçőes nas estratégias de proteção óssea. 
Biomecanicamente, o tecido ósseo pode ser visto como um material composto bifásico, com mineral em uma fase (Cálcio e Fosfato Ca10(PO4)6 (OH)2) e colágeno e substância de base em outra (Fibras de colágeno tipo I orientadas de forma variada). As substâncias combinadas são mais fortes em relação aos seus pesos do que cada qual separadamente, dando ao tecido ósseo capacidade de resistir a forças e momentos em várias direções. Por conta da estrutura do osso não ser similar nas direçōes transversas e longitudinais, o osso exibe propriedades mecânicas diferentes quando carregados em diversos eixos, uma caracteristica conhecida como anisotropia. A anisotropia desse material o torna mais resistente a cargas compressivas e menos resistente a forças tensionais, sendo de responsabilidade dos músculos o controle das cargas tensionais nocivas ao osso (NORDIN\&FRANKEL, 2003).

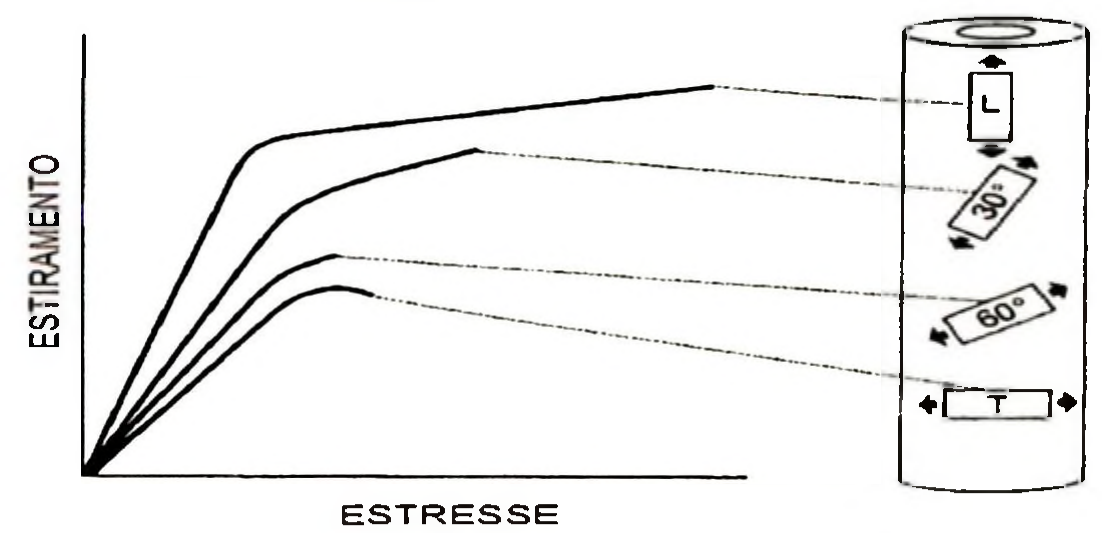

Figura 2: llustraçåo do comportamento do tecido ósseo diante de diferentes àngulos de aplicaçăo de carga. Sendo do ponto zero ao ponto de deflexăo da curva o momento correspondente a zona elástica do tecido, o ponto de deflexăo correspondente a transiçăo entre a zona elástica e a zona plástica, do pondo de deflexåo ao final da reta o momento correspondente a zona plástica e o ponto final da reta correspondente ao momento de falha do tecido. Adaptado de NORDIN\&FRANKEL (2003).

Além das características morfológicas, fatores fisiológicos também são responsáveis pela anisotropia do tecido. Quando carregado mecanicamente ossos humanos, produzem uma polarizaçāo elétrica, convertendo a energia mecânica em energia elétrica, através do efeito piezelétrico (FUKADA \& YASUDA, 1957). O ângulo de aplicação de carga no osso contribui diretamente para síntese ou reabsorção do tecido ósseo através da polaridade das cargas liberadas. Quando 
exposto a cargas compressivas, o tecido ósseo gerar cargas negativas que atraem moléculas de cálcio para o seu interior. Já quando exposto à esforços de tração, serão geradas cargas positivas que vão repelir as moléculas de cálcio favorecendo a reabsorção óssea. Desta forma, sendo o osso um material piezelétrico, deformaçōes mecânicas variadas, a tração, compressão ou torção podem causar nesse tecido alteraçōes morfológicas (LIRANI \& LAZARETTI-CASTRO, 2005).

Durante a locomoção humana, as forças externas geradas pela interaçāo entre o aparelho locomotor e o meio externo, serāo transmitidas para o tecido ósseo, podendo gerar em uma de suas superficies compressāo, enquanto a superfície oposta sofre forças de tração (YOSHIKAWA et.al., 1994).

Sendo a carga imposta ao osso um fator determinante para o seu desenvolvimento ou degeneraçăo, os fatores relacionados ao controle de carga podem ser decisivos para o tecido ósseo. Quando bem aplicadas, as cargas poderão promover um desenvolvimento desse tecido, fato reverso ocorrerá caso essas cargas nāo sejam controladas, sendo esse um fator desencadeante de uma fratura por estresse(MILGROM, 2007).

As primeiras evidências sobre o estiramento ósseo e as fraturas atraumáticas foram observadas por CARTER et al. em 1981 usando fêmures humanos. Em um teste mecânico, foi observado que o osso entra em falha dentro 1-1000 ciclos de carga quando a força de traçăo variar entre 5000 e 10000 microestiramentos $(\mu \varepsilon)$. A variação da força de traçăo na ordem de $6000 \mu \varepsilon(-3000$ e +3000) causou a falha óssea em 2147 ciclos. Isso se traduz em cerca de $3 \mathrm{~km}$ de corrida. Uma traçāo axial em $3000 \mu \varepsilon$, ligeiramente maior do que a picos de tração normal in vivo, causou falha óssea a 100 mil ciclos de carga (YOSHIKAWA et.al., 1994). Isso mostra que o controle das cargas impostas no tecido ósseo, pode ser fator determinante para sua constituiçăo, uma vez que a carga necessária para causar falha óssea é mais alta do que o estresse gerado por atividade vigorante, além do que, o aparelho locomotor dispōe de diversas estratégias para controlar as cargas que the săo impostas (MILGROM, 2007).

Analisando diferentes formas de locomoçāo, MILGRON (2000), observou que situaçōes como caminhada e corrida vảo gerar respectivamente na ordem de 840 e $1378 \mu \varepsilon$ de traçāo na regiāo da tibia. O autor afirma que essa carga pode năo ser suficiente nem para gerar ativação de formaçăo óssea, pois estudos feitos em ratos mostraram uma necessidade de uma carga que gerasse acima de1050 $\mu \varepsilon$ para 
ativação da formação óssea.

RUBIN et al.(1984) em um ensaio mecânico, carregaram de forma isolada a ulna

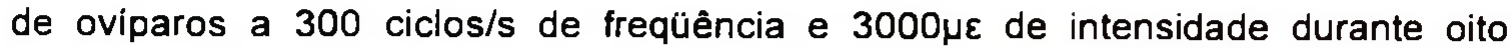
semanas, observando nesses animais aumento significativo de suas propriedades geométricas devido ao aumento da mineralizaçăo periosteal. Animais da mesma espécie, porém em idade avançada, submetidos às mesmas condiçōes, não apresentaram aumento em suas propriedades geométricas, mas apresentaram uma maior espessura média da parede óssea.

Segundo ROMANI (2002), as cargas mecânicas geradas pela atividade física desencadeiam no tecido ósseo um processo de remodelaçăo. Com o aumento do estresse durante a atividade ocorrerá uma aceleração deste processo de remodelação seguido de um enfraquecimento do osso e maior susceptibilidade à fratura por estresse.

$\mathrm{Na}$ tentativa de minimizar as cargas externas ao tecido ósseo, a contração muscular exerce um papel fundamental (MIZRAHI, 2000). Músculos e outros tecidos moles podem dissipar as forças dinâmicas no esqueleto pela ação excêntrica evitando assim o estiramento tecidual ósseo (PAUL et. al,1978; PAUWELS, 1980; MCMAHON, 1984; BERGMANN et. al, 1991).

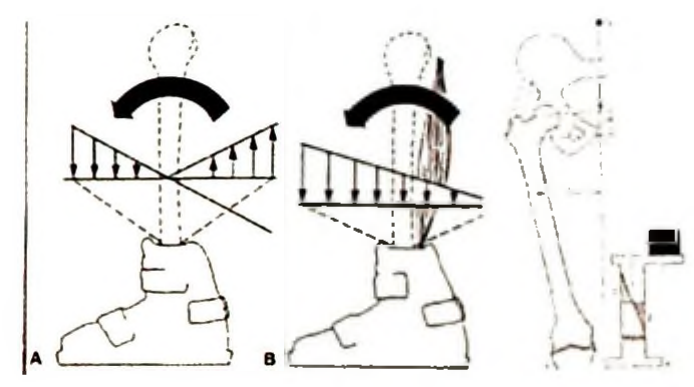

Figura 3- Caracterização do fator de proteção muscular ao tecido ósseo. Adaptado de NORDIN \& FRANKEL (2003).

Se contraçāo muscular excêntrica pode reduzir a tração no osso durante o movimento, fraturas de estresse podem ser evitadas desde que a capacidade dos músculos de proteger os ossos de sobrecargas năo seja excedida. (YOSHIKAWA et.al., 1994; MIZRAHI, 2000). Segundo MILGROM (1985), a não proteção óssea 
decorrente de uma fadiga muscular, pode ser o principal fator que contribui para o aumento da incidência de fraturas por estresse.

As fraturas por fadiga e ou estresse são mais comuns quando os ossos são repetitivamente carregados acima de um determinado ponto inicial de compressão ou traçăo (YOSHIKAWA et.al., 1994). Tais estiramentos ocorrem nos ossos em resposta aos ciclos múltiplos do excesso repetitivo das cargas, quando a habilidade do corpo de atenuar forças externas é excedida (MIZRAHI, 2000).

A fadiga ou incapacidade do músculo está associada com um aumento na traçāo óssea, podendo alterar a distribuição da tração dentro do osso. Isto pode contribuir ao desenvolvimento de fraturas por estresse naqueles casos em que a fratura ocorre subseqüente ao exercicio de extenuante (MIZRAHI, 2000).

YOSHIKAWA et.al., (1994) após exporem dez cães a um protocolo de fadiga de 20 minutos de caminhada em esteira apenas sobre as patas traseiras monitorados por células de carga implantadas na tíbia, observaram um aumento da deformação óssea em todos os cāes, fato esse que não ocorreu enquanto os músculos do aparelho extensor e flexor do joelho não estavam fadigados. Outros fatores que chamaram a atenção foram a alteração dos pontos de aplicação da carga e do tipo de deformação. Após a fadiga, a máxima força de tração aumentou significativamente sobre o córtex anterolateral da tíbia, mostrando um aumento da traçăo média na ordem de $35 \%$. A distribuição da tração também mudou, o maior aumento percentual em traçăo ocorreu perto do eixo neutro ao longo do córtex posterior, onde as tensōes antes do exercicio eram reduzidas. Isso ocorreu principalmente a uma rotaçāo de $25^{\circ}$ da tíbia no sentido horário da linha neutra após a fadiga. Esses dados, concluem os autores, mostram que os fatores desencadeantes de uma fratura por estresse como perda de massa óssea, alterações nos padrōes de movimento normal ou perda de coordenação podem estar associados a incapacidade muscular.

Buscando melhor entendimento da hipótese da fadiga comprometer a ação muscular protetora, MIZRAHI (2000) avaliou o desequilibrio entre as atividades dos músculos plantiflexores e dorsiflexores do tornozelo testando 40 sujeitos durante um treino de corrida com limiares anaeróbicos. Os músculos tibial anterior e gastrocnemio medial foram monitorados por eletromiografia de superfície e um acelerômetro fixado a tuberosidade da Tíbia. Após o desenvolvimento da fadiga muscular, observou-se uma diminuiçăo significativa do valor integral do sinal 
eletromiográfico para o músculo Tibial anterior em paralelo com um aumento da aceleraçăo na Tíbia. O autor conclui que essa combinaçăo pode impedir o equilíbrio das cargas na tibia sendo um possivel fator desencadeante de fraturas por estresse.

MILGROM et. al (2007), mediram as taxas de traçăo interna do osso humano antes e depois atividades físicas desgastantes através de grampos ortopédicos $16 \times 15 \mathrm{~mm}$ (3M Health Care, St. Paul, Minnesota) calibrados para micro medidas de tração, implantados cirurgicamente na tíbia de quatro voluntários. Os sujeitos foram submetidos a um protocolo de fadiga de $5 \mathrm{hs}$ de atividades intensas (Tiros de corrida do Basquetebol, saltos de rebote, laterais e verticais, hopping em zig-zag, e sprints em bicicleta). Após essa primeira etapa, os voluntários tiveram um descanso de 1 hora e iniciaram uma marcha de 30 quilômetros sobre a terreno montanhoso do deserto e em um ritmo forçado de $6 \mathrm{~km} / \mathrm{h}$ a uma temperatura na escala de $25-30^{\circ} \mathrm{C}$.

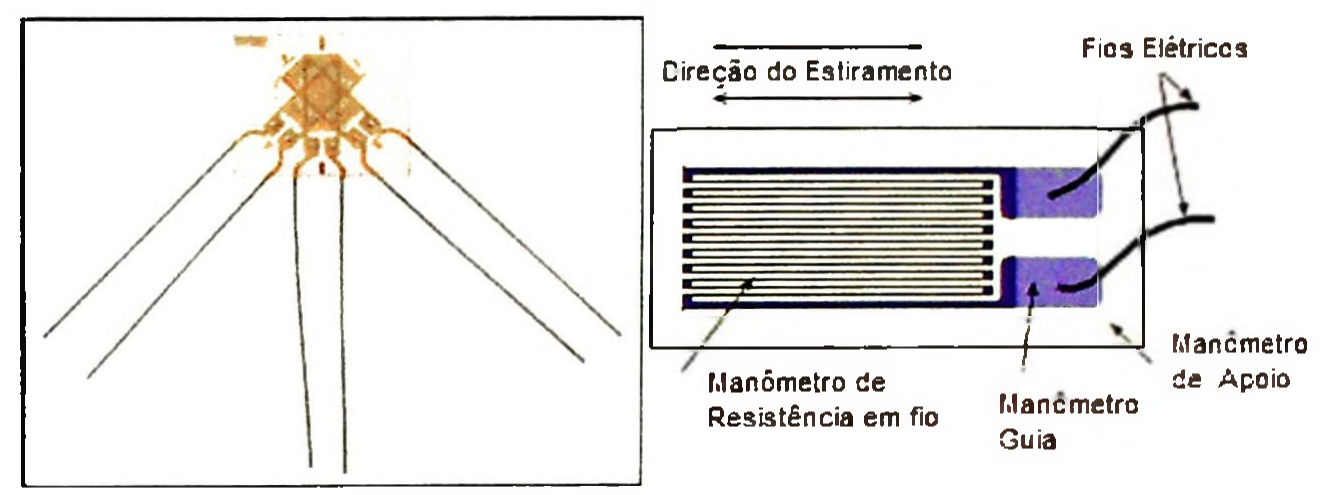

Figura 4 llustraçåo de um Strain-Gauged Staples (SGS) $30^{\circ} \mathrm{em}$ padråo de roseta - grampos para aferir tração interna - 3M Health Care, St Paul, Minnesota).

Foram inseridos percutaneamente na Tibia dos voluntários, SGS em aspecto de rosetas a $30^{\circ}$. Foi mensurada a traçāo tibial, o torque isocinético do tornozelo e a força reação do solo em 4 sujeitos antes e depois das duas etapas de exercicio.

(a)

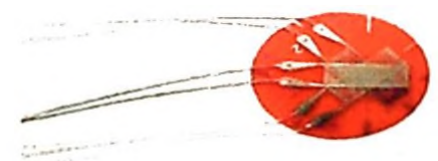

(b)

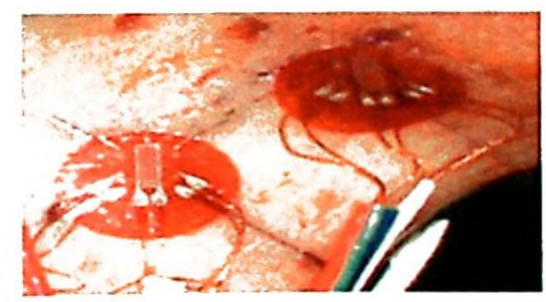

Figura 5- llustração da fixação das SGS na tlbia de soldados para o monitoramento das forças internas no tecido ósseo durante diferentes condiçóes de fadiga. 
Após a realização das duas etapas do exercício, os resultados encontrados, deixam clara a influência da fadiga/incapacidade muscular nas propriedades do tecido muscular e também os efeitos da incapacidade muscular no tecido ósseo. Diferenças significativas foram encontradas tanto no torque isocinético (redução de $37,31,23$ e $21 \%$ no pico de torque do músculo Gastrocnemio) quanto na deformação da Tíbia (aumento de $26 \%$ das forças de tração anterior pós corrida e $29 \%$ pós marcha no deserto, aumento das taxas da força de tração em $13 \%$ pós corrida e $11 \%$ pós marcha no deserto, diminuição das forças de compressăo em $15 \%$ pós corrida e $24 \%$ pós marcha no deserto, aumento das taxas de força de compressão em $9 \%$ pós corrida e $17 \%$ pós marcha no deserto), evidenciando que o estado de fadiga pode alterar significativamente as tensỏes ósseas, condição essa que favorece o surgimento de fraturas por estresse.

Embora diversos autores apontem que a fadiga muscular aumente a tração no tecido ósseo, nada foi encontrado a respeito do aumento do tempo de latência após aplicação de um de um determinado estimulo e sua influência no osso. Também não foi encontrado nenhum tipo de material que apresente relação do tempo de latência muscular e fraturas por estresse.

\subsection{Instrumentos de Medição Usados na Avaliação Biomecânica}

2.1.4 Plataforma de Força de Reação do Solo como método de investigação.

A plataforma de força de reação do solo é um dos instrumentos da dinamometria para medir as variáveis dinâmicas do movimento, permitindo a quantificaçāo das cargas externas (AMADIO \& DUARTE, 1998; NIGG, 1986; WINTER, 1990). Estas variáveis podem ser adquiridas através da análise de movimentos da locomoção, tais como, a corrida e os saltos, que são os movimentos de interesse deste estudo.

Os principais indicadores das cargas externas podem ser obtidos pela análise da componente vertical da FRS. Entre eles, o primeiro pico de força (Fy1), o tempo para alcançar Fy1 ( $\Delta t$ Fy1) e o gradiente de crescimento (GC) são de reconhecida relevância para análise dos movimentos por permitirem a quantificação do impacto aplicado ao aparelho locomotor (AMADIO \& DUARTE, 1998). A importância em se analisar tais variáveis para correlacionar a percepçăo às cargas 
mecânicas também é destacada na literatura especializada (HENNIG, VALIANT \& LIU, 1996; LAKE \& LAFORTUNE, 1998; MILANI, HENNIG \& LAFORTUNE, 1997).

2.1.5 Uso da Plataforma de Força de Reação do Solo como método de investigaçäo nas fraturas por estresse.

A Força de Reação de Solo (FRS) é um fator importante no estudo da cinética das extremidades inferiores, durante a locomoção. Ela tem sido usada em uma variedade experimental, principalmente em corredores. Relativamente fácil de ser medida, vários autores tem usado esse recurso para comparar as caracteristicas cinéticas entre grupos que já apresentaram episódios de Fraturas por estresse de Tibia e grupos controle, tentando explicar assim, a associaçāo entre eles no que se refere as forças durante a prática esportiva (ZADPOOR \& NIKOOYAN, 2011).

Parâmetros derivados da FRS, como o pico da força, o tempo para o pico e o GC são apontados pela literatura como importantes indicadores das cargas externas impostas ao aparelho locomotor (MUNRO,1987;LIU\&NIGG,2000; ZADPOOR et al, 2007; ZADPOOR \& NIKOOYAN, 2011).

O entendimento das variáveis da FRS apresentada por grupos que possuem histórico de Fraturas por Estresse e uma possivel correlação entre as fraturas e a carga permitiria um melhor desenho de futuros estudos e uma melhor compreensão da etiologia dessa lesāo, que atualmente não è bem compreendida. Poder-se-ia ainda usar a FRS como uma ferramenta relativamente barata no diagnóstico de fatores predisponentes da lesāo, auxiliando assim em sua prevenção, acompanhamento evolutivo do tratamento.

Porém, existe uma discordância entre os resultados dos estudos que usaram as variáveis da FRS para comparar grupos saudáveis com grupos acometidos por fraturas por estresse de tíbia. Enquanto alguns autores concluem que não há diferença significativa nas variáveis de FRS entre grupos acometidos por Fraturas de Estresse e grupo controle, outros relatam uma diferença substancial. (ZADPOOR \& NIKOOYAN, 2011). 
Tabela 1 Conclusão de autores quanto as diferenças encontradas nas variáveis de FRS entre grupos de corredores que apresentaram fraturas por estresse quando comparados a um grupo controle (adaptado de ZADPOOR \& NIKOOYAN, 2011).

\begin{tabular}{|c|c|c|}
\hline \multirow[t]{2}{*}{ Autores } & \multicolumn{2}{|l|}{ Conclusð̄es } \\
\hline & Pico de força & GC da força \\
\hline Creaby and Dixon (2008) & $\begin{array}{l}\text { Nåo observou diferenças } \\
\text { significativas entre os grupos. }\end{array}$ & - \\
\hline Pohl et al. (2008) & - & $\begin{array}{l}\text { Não observou diferenças } \\
\text { significativas entre os grupos. }\end{array}$ \\
\hline Bennell et al. (2004) & $\begin{array}{l}\text { Nảo observou diferenças } \\
\text { significativas entre os grupos. }\end{array}$ & $\begin{array}{l}\text { Não observou diferenças } \\
\text { significativas entre os grupos. }\end{array}$ \\
\hline Milner et al. (2006a) & $\begin{array}{l}\text { Não observou diferenças } \\
\text { significativas entre os grupos. }\end{array}$ & $\begin{array}{l}\text { Grupo com história de Fratura } \\
\text { por estresse apresentou MAIOR } \\
\text { GC. }\end{array}$ \\
\hline Zifchock et al. (2006) & - & $\begin{array}{l}\text { Grupo com história de Fratura } \\
\text { por estresse apresentou MAIOR } \\
\text { GC. }\end{array}$ \\
\hline Davis et al. (2004) & - & $\begin{array}{l}\text { Grupo com história de Fratura } \\
\text { por estresse apresentou MAIOR } \\
\text { GC. }\end{array}$ \\
\hline Ferber et al. (2002) & $\begin{array}{l}\text { Grupo com história de Fratura } \\
\text { por estresse apresentou } \\
\text { significativamente MAIOR Pico } \\
\text { de força. }\end{array}$ & $\begin{array}{l}\text { Grupo com história de Fratura } \\
\text { por estresse apresentou } \\
\text { significativamente MAIOR GC. }\end{array}$ \\
\hline Crossley et al. (1999) & $\begin{array}{l}\text { Năo observou diferenças } \\
\text { significativas entre os grupos. }\end{array}$ & $\begin{array}{l}\text { Nảo observou diferenças } \\
\text { significativas entre os grupos. }\end{array}$ \\
\hline Grimston et al. (1994) & $\begin{array}{l}\text { Grupo com história de Fratura } \\
\text { por estresse apresentou } \\
\text { significativamente MENOR Pico } \\
\text { de força. }\end{array}$ & \\
\hline Grimston et al. (1991) & $\begin{array}{l}\text { Grupo com história de Fratura } \\
\text { por estresse apresentou } \\
\text { significativamente MAIOR Pico } \\
\text { de força. }\end{array}$ & \\
\hline Bischof et al. (2010) & $\begin{array}{l}\text { Não observou diferenças } \\
\text { significativas entre os grupos. }\end{array}$ & \\
\hline Queen et al. (2009) & $\begin{array}{l}\text { Grupo com história de Fratura } \\
\text { por estresse apresentou } \\
\text { significativamente MENOR Pico } \\
\text { de força. }\end{array}$ & \\
\hline
\end{tabular}




\subsubsection{A Eletromiografia como técnica de investigação}

A EMG è uma técnica muito difundida atualmente. Esta é utilizada para o estudo dos sinais elétricos que o músculo recebe do sistema nervoso, avaliando-se assim os potenciais elétricos e suas variaçōes, para desta forma traçar um parâmetro do nivel de participação dos músculos, durante a sua contração (AMADIO, 2002).

Pontuando sobre as aplicações da EMG, DE LUCA, (1993) cita a de análise do tempo de ativação muscular; a tentativa de traçar uma correlação entre EMG/Força e seu uso como análise da fadiga. Já ARAÚJO, (1998) assume, além das aplicações descritas anteriormente, outras aplicações como o estudo da função muscular em movimentos e posturas pré-selecionadas, a análise da atividade muscular em modalidades esportivas, as análises de condições clínicas $e$, laborais, validação anatômico-funcional da atividade muscular e análise dos efeitos do treinamento e sua especificidade.

Desta forma, DAINTY E NORMAN (1987) descrevem está técnica como sendo eficiente para demonstrar uma ação da musculatura em movimentos atléticos, em exercicios físicos, reabilitacionais e/ou ergonômicos em seres humanos (sintomáticos ou assintomáticos), pois estes dados, quando bem controlados, são um parâmetro válido e uma medida segura da habilidade humana.

O uso da EMG para descrever a função e coordenação muscular tem sido classificado em uma área conhecida como EMG cinesiológica, realizada através da complexa análise. As áreas de aplicação da EMG cinesiológica podem ser descritas da seguinte maneira (CLARYS \& LEWILLE, 1992):

a)Estudos da função muscular normal durante movimentos e posturas selecionados;

b)Estudos sobre a atividade muscular em movimentos complexos esportivos, ocupacionais e de reabilitação;

c)Estudos na contração isométrica com aumento da tensão, relativa à contração voluntária máxima;

d)Avaliação da atividade muscular anatômico-funcional (validação de funções anatômicas clássicas); 
e)Estudos sobre coordenação e sincronização (cadeias cinéticas);

f)Estudos sobre eficiência de métodos de treinamento;

g)Estudos de fadiga;

h)Relação EMG e força;

i)A interação homem-máquina: estudos ergonômicos sobre a influência de material usado pelo homem na atividade muscular;

j)Investigaçāo das característica do movimento esportivo, na busca de melhora de seu desempenho e prevenção, controle evolutivo e reabilitação de lesões.

Infelizmente a EMG, por ser uma técnica que oferece fácil acesso aos processos neurofisiológicos que ocorrem em um músculo quando de sua solicitação, envolve fatores que acabam por influenciar no sinal eletromiográfico, ocasionando mudança deste, afetando sua magnitude, suas caracteristicas e gerando erros em sua interpretação. Estas interferências são advindas de vários fatores que dificilmente podem ser evitados, como as perturbaçōes da rede elétrica, aparelhos eletro-eletrônicos utilizados nas proximidades da coleta, localização do eletrodo, tamanho deste e sua área de varredura, má colocação e fixação do eletrodo, da friç̧ão entre este e sua área de contato quando de um movimento, distância entre os filamentos do eletrodo, a impedância causada pelo tecido adiposo sobre o músculo analisado, temperatura corpórea e muscular, da transpiração produzida pelo corpo humano, área de secção transversa, comprimento muscular, entre outros. (DE LUCA, 1993; WINTER, 1990)

Além desses fatores, o sinal eletromiográfico varia em função das propriedades fisiológicas e anatômicas do músculo, dependendo do esquema de controle do sistema nervoso periférico, fazendo com que a magnitude da tração mecânica, a velocidade de encurtamento e alongamento do feixe muscular, à taxa de tração do músculo, a fadiga e a atividade reflexa possam vir a dificultar a interpretação deste sinal (ARAÚJO, 1998, ACIERVO, BARATTA \& SOLOMONOW. 1995).

Dentre os fatores que afetam na captação do sinal encontram-se os eletrodos utilizados em EMG. O sinal eletromiográfico pode ser captado por eletrodos passivos ou ativos, podendo ser divididos em eletrodos de superfície (tri polar, bipolar e mono polar) e eletrodos intramusculares para captaçăo de sinal em músculos profundos (eletrodos de agulha e eletrodo de fio). 


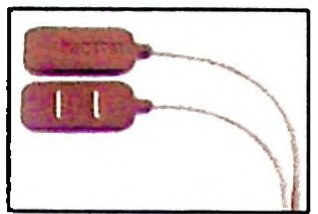

A

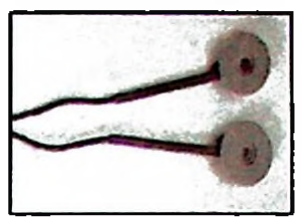

B

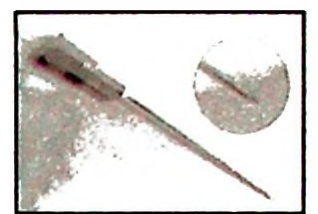

C

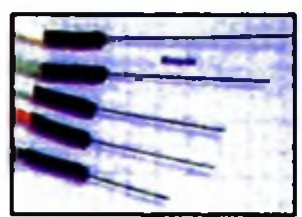

D

Figura 6- Eletrodos comumente utilizados na captação do sinal eletromiográfico. Eletrodo Ativo (A), Eletrodo Passivo (B), Eletrodo Intramuscular de fio (C) e Eletrodo Intramuscular de agulha (D).

A principal diferença encontrada entre os eletrodos ativos e passivos está no fato de que os eletrodos ativos produzem uma pré-amplificação do sinal, pois possuem um amplificador diferencial dentro de sua estrutura. O sinal é detectado em dois lugares e os circuitos eletrônicos subtraem e amplificam a diferença encontrada entre estes dois sinais obtidos. Em conseqüência o sinal advindo do eletrodo de referência (terra), que é comum a ambos os sinais, foi eliminado e os sinais que forem diferentes nos dois locais terão um diferencial que é amplificado. Para que isto aconteça é necessário que a subtração seja exata e perfeita, o que acaba por nāo acontecer realmente. Esta exatidão é medida pela relação do modo comum de rejeição (MCR), onde uma subtração perfeita exige um MCR infinito.

Há atualmente MCR de $1200 B$, mas existem pelo menos duas razōes que impossibilitam sua utilização: $O$ alto custo de tais dispositivos, e sua deficiência para manter a estabilidade elétrica. (DE LUCA, 2002).

Quando se utiliza eletrodos de superfície levam-se em conta alguns fatores em relação ao tipo de captação do eletrodo, bem como a distância entre estes, que pode interferir no número de fibras que são captadas, o que acaba por afetar a amplitude do sinal. Em um trabalho realizado por DE LUCA (1993), ele remete a atenção que se deve dar quanto à posição em que estes eletrodos são colocados, para assim não haver uma interferência na amplitude do sinal e na freqüência de espectro deste.

Outro importante fator de interferência é o crosstalk, fenômeno condicionado pela uma interferência advinda de um músculo adjacente ao analisado. DE LUCA \& MERLETTI (1988) apontam que $17 \%$ da atividade elétrica verificada no reto femoral da perna direita, é uma interferência do músculo mais próximo ao analisado, 
podendo haver uma redução neste fator se o eletrodo for colocado na porção média do músculo analisado, já que o tecido entre os músculos e dentro destes são anisotrópicos e não homogêneos.

\subsubsection{Tratamento matemático do sinal eletromiográfico.}

Uma vez que o sinal eletromiográfico foi amplificado, este deve ser processado para a comparação e/ou correlaçāo com outros sinais fisiológicos ou biomecânicos. Neste processo utilizam-se procedimentos matemáticos para proceder tal comparação e/ou correlação. Isto se dá devido ao fato de que o sinal sem amplificaçāo, filtragem ou tratamento matemático não irá dispor de informaçōes precisas para as futuras análises (WINTER, 1990).

Um dos tratamentos aplicado ao sinal eletromiográfico é conhecido como retificação. Segundo ARAUJO (1998) esta retificação pode ser feita através da retificação de meia-onda que é o processo no qual os valores negativos encontrados no sinal sāo eliminados do procedimento de análise. $\mathrm{Na}$ retificação de onda completa somente as magnitudes absolutas do sinal são consideradas, essa normalmente é preferida, já que preserva o sinal original.

Após o processo de retificação do sinal, este pode continuar apresentando dois problemas para sua interpretação motivados pelos ruidos internos e externos. Para minimizar tais problemas, utilizam-se os filtros digitais.

Um filtro é um dispositivo elaborado para atenuar as escalas especificas das freqüências, permitindo que as outras escalas passem. Assim limitando de alguma forma o espectro do sinal a fim de minimizar os erros provenientes de uma eventual distorção.

A filtragem do sinal se faz de extrema importância para o processamento deste. Em todo sistema AVD (analógico/digital) de aquisiçăo, a freqüência de interrupção do filtro de redução deve ser sempre menor que a metade da freqüência de amostragem. Enquanto os filtros analógicos são mais apropriados para o condicionamento do sinal, os filtros digitais såo empregados para minimizar os ruidos. (DE LUCA, 2003).

Quanto aos filtros utilizados estes, que atenuam a ordem de freqüência são conhecidos como stopband e a escala que passa é conhecida como passa-banda . Dentre os filtros passband há aqueles chamados de passa-baixa, passa - alta e 
passa-banda. (DE LUCA, 2003).

Sabendo que os filtros atuam na remoção dos possíveis ruídos e das possiveis distorções que ocorrem na captação e no processamento do sinal eletromiográfico, os filtros comumente utilizados são os filtros Butterworth, Chebyshev, Elliptic e Thompson (filtro de Bessel). (DE LUCA, 2003)

Após a diminuição dos ruídos, o contínuo processamento deste sinal se faz necessário, pois irá melhorar as estratégias para a interpretação deste. Sendo que o processamento adotado para o sinal EMG é de grande importância, pois assim facilitarà a interpretação do comportamento da ativação muscular.

Este processamento pode ser efetivado a partir de diferentes procedimentos, dentre as quais se destacam, em função da possibilidade de preservar a potència do sinal, a integração e o Root Mean Square (RMS). A integral do sinal EMG é obtida a partir da integração matemática do sinal. Esta integração seria aplicada apenas a sinais retificados e o seu valor tende a aumentar em função do tempo. Root Mean Square é matematicamente definido como a raiz quadrada da média dos quadrados dos valores instantâneos do sinal, sendo este um bom indicador da magnitude do sinal, pois representa a potência deste, quando da realização de contrações voluntárias (ARAÚJO, 1998; DE LUCA, 1988; WINTER, 1990).

Outro importante passo no tratamento do sinal eletromiografico diz respeito à normalizaçāo.

O sinal EMG apresenta variabilidade quando comparadas diferentes execuções do mesmo indivíduo ou de indivíduos diferentes. O valor absoluto da intensidade do sinal EMG fornece pouca informaçăo, principalmente quando os sinais săo captados de individuos ou condiçōes diferentes. Para solucionar esta limitação, se faz necessário à normalização em amplitude da curva eletromiografica, em função de um valor de referência de amplitude, permitindo a comparação intra e inter-individuos, e inter-condiçōes (LUDIN, 1995).

Segundo WINTER (1990) há três possibilidades de valor de referência para essa normalização: a média da intensidade, o seu valor máximo, e a contração voluntária máxima isométrica (CMVI).

Segundo ARAÚJO (1998) ao realizarmos a normalizaçăo do sinal pela contração voluntária máxima isométrica (CMVI), temos que considerar um erro de $21,61 \%$, sendo que o porque deste não foi encontrado na literatura. Ao invés da normalização pelo sinal CVMI seria melhor se utilizássemos o valor da onda-M 
média, pois, através dessa, o estímulo elétrico pode ser controlado de acordo com as suas variações em diferentes ângulos do movimento, o que não ocorre em uma contração voluntária isotônica. Além disso, ao normalizarmos pela CVMI, este valor pode não condizer com o restante da curva de sinal, mas ao mesmo tempo ser uma fonte de parâmetro quanto à intensidade de ativação do músculo. Já quando o sinal é normalizado pela média da curva, este valor expressa de forma mais clara como este sinal se dá, mas ao mesmo tempo perde-se o parâmetro de intensidade de ativaçāo máxima.

\subsubsection{Eletromiografia como técnica de investigação na fratura por estresse}

Em tempos atuais, existe um vasto número de relatos na literatura sobre o uso da eletromiografia na investigação das fraturas por estresse.

Segundo MIZRAHI (2000) através desse recurso, pode-se investigar a fadiga periférica e suas consequências no equilibrio muscular da articulação do tornozelo, aumentando a tendência de extensão e diminuindo a tendência de flexão, porém, em um de seus esperimentos, a integral do sinal eletromiográfico após protocolo de fadiga nāo sofreu nenhuma alteração. O autor ainda afirma que, durante uma corrida rápida, a ação antecipatória do tibial anterior é fundamental para absorção das cargas geradas pelo movimento.

Segundo CAVANAGH (1990), para que o controle da carga seja eficaz, existe a necessidade do músculo tibial anterior exercer uma a alta atividade nos $50 \mathrm{~ms}$ que antecedem o toque do calcâneo ao solo no final da passada de uma corrida.

Uma falha do músculo tibial anterior nesse momento, aumenta a velocidade de choque da tibia com o solo, fator esse que está intimamente ligado ao surgimento de uma fratura por estresse (MILGROM, 1985). 


\section{MATERIAIS E MÉTODOS}

\subsection{Amostra}

A amostra foi composta por 24 atletas do gênero feminino com idade média de $18 \pm 1$ anos das equipes Juvenil e Infanto Juvenil de um programa de seleção e promoção de talentos esportivos sediado na cidade de Osasco-SP, sendo que, 17 atletas constituiram o grupo controle e 7 atletas constituiram o grupo experimental.

Por se tratar de um grupo homogêneo, tanto no que se refere às caracteristicas fisicas e nutricionais das voluntárias quanto no que tange ao programa de treinamento, o grupo selecionado permitiu um bom controle destas importantes variáveis.

Foram considerados critérios de inclusão para a composição do grupo experimental os seguintes aspectos:

a) Ser atleta federado de Voleibol ou Basquetebol, modalidades estas selecionadas por envolvem movimentos de saltos e deslocamentos com alterações bruscas de direção;

b) Praticar a atividade, em regime competitivo, há pelos menos cinco anos de forma ininterrupta;

c) Apresentar diagnóstico médico de lesão óssea atraumática primária ou reicidivante em grau I ou II nos dois anos que antecederam a coleta.

Foram excluidas do grupo experimental as voluntárias que apresentaram dor aguda ou crônica relacionada ao episódio de fratura por estresse no momento do teste, voluntárias que apresentaram qualquer lesão osteomioarticular, que não fraturas por estresse, nos 6 meses antecedentes ao teste e voluntárias que apresentaram alguma disfunçăo hormonal em exames de rotina realizados semestralmente no clube de origem no ultimo ano.

A composição do grupo controle se deu a partir da observação dos seguintes critérios:

a) Ser atleta federado de Voleibol ou Basquetebol;

b) Praticar a atividade, em regime competitivo, há pelos menos cinco anos, de forma ininterrupta.

Foram excluidas do grupo controle as voluntárias que apresentaram qualquer tipo de lesăo osteomioarticular nos últimos 6 meses. 


\subsection{Método de Diagnóstico}

Todas as voluntárias foram recrutadas através de um registro prospectivo de lesões realizado de janeiro de 2005 a dezembro de 2008 no clube de origem. Os diagnósticos foram orientados seguindo o protocolo médico adotado pelo departamento médico do clube de origem que baseou-se em:

1- história - dor insidiosa e progressivamente limitante da atividade esportiva;

2- exame físico geral e ortopédico - dor local e edema, que resultou em diminuiçāo do rendimento em quadra;

3- alteração nas imagens tardias coletadas em exame de Cintilografía Óssea Trifásica utilizando traçador radioativo metilenodifosfonato (MDP), marcado com tecnécio-99m (MDP_ ${ }^{99 m} \mathrm{Tc}$ ) que graduassem a lesāo em grau I ou II seguindo a graduação de ZWAS(1987). Todos os exames foram realizados na Unidade Radiológica Paulista (URP), unidade Ibirapuera.

\subsection{Procedimento experimental}

Após ter passado pelos critérios de inclusão e exclusāo, ter sido informado dos riscos e benefícios da participação no trabalho e ter assinado o consentimento informado em participação da pesquisa (Anexo 1), as voluntárias foram submetidas a condições experimentais que envolviam movimentos básicos como mudanças bruscas de direção e salto vertical e movimentos especificos da modalidade praticada. Tais condições foram escolhidas por se caracterizarem como movimentos característicos das modalidades esportivas praticadas pelas voluntárias. Para caracterizar movimentos especificos relacionados ao salto vertical, as atletas que praticavam voleibol realizaram o gesto de bloqueio e as que praticavam basquetebol realizaram o gesto de bandeja. Em um segundo momento, objetivando-se buscar uma maior especificidade do salto horizontal, atletas praticantes de voleibol foram orientadas a realizar o gesto de ataque enquanto as praticantes de basquetebol foram orientadas a realizar o gesto de bandeja.

A investigação foi realizada através de instrumentos que permitem avaliar o movimento em suas manifestaçōes dinâmicas e Eletromiográficas, seguindo o 
seguinte fluxograma (Figura 7).

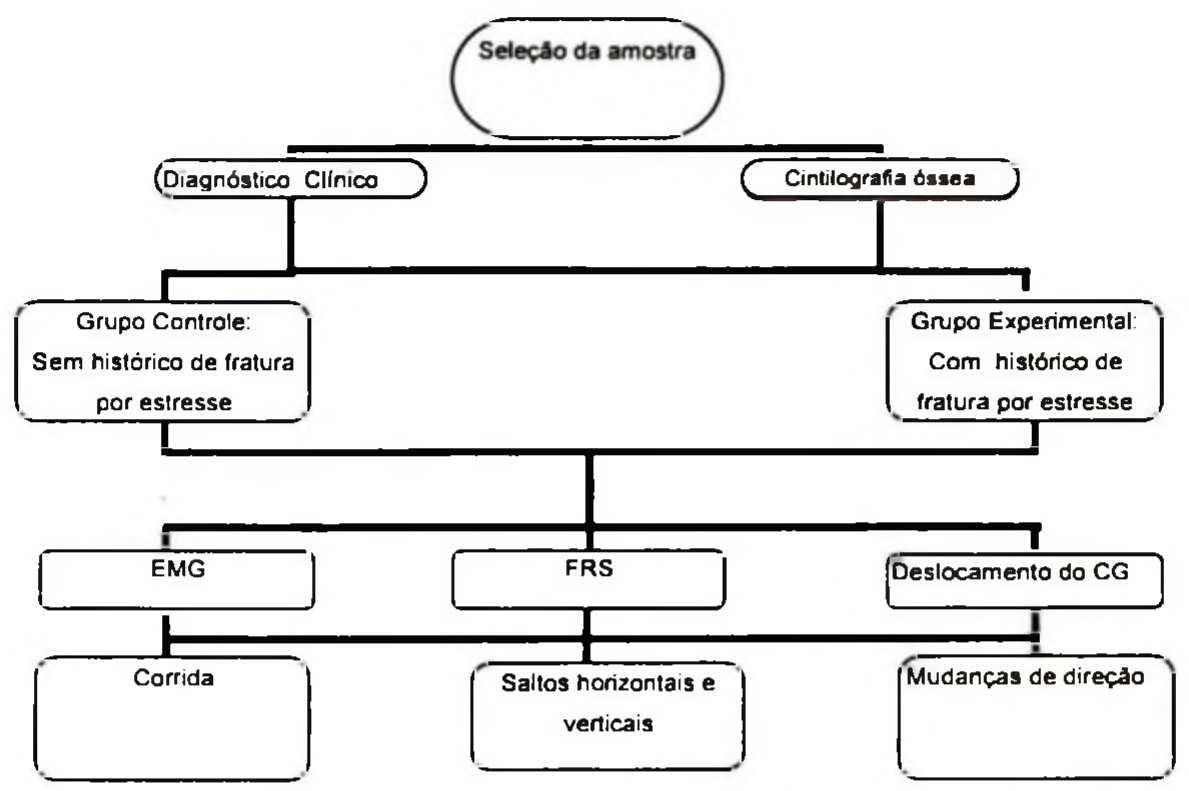

Figura7: Fluxograma que ilustra as etapas do procedimento experimental

\subsection{Preparação do Sujeito}

Durante a realizaçāo da tarefa, as voluntárias foram monitorados por eletromiografia de superficie com eletrodos posicionados nos músculos Tibial Anterior e Gastrocnemio Cabeça Medial em ambos os membros. Os eletrodos foram posicionados seguindo as recomendações de (SENIAM, 2006) que preconizam o posicionamento dos eletrodos na porção mais proeminente do músculo Gastrocnêmico medial e a $1 / 3$ da linha entre a cabeça da fibula e o maléolo medial para o Tibial Anterior. Um eletrodo de referência, mono polar, foi posicionado sobre a Espinha llíaca Antero Superior.

Para um melhor posicionamento dos eletrodos em cada um dos músculos, foi realizada a tricotomia do local e a esfoliação com lixa fina. Tal procedimento foi necessário para remover a camada sebácea da pele e conseqüentemente diminuir a impedância da interface eletrodo-pele, facilitando a aquisição do sinal. A seguir, os eletrodos de superficie foram acoplados sobre a pele dos individuos através de uma 
fita adesiva usada externamente ao eletrodo para garantir a fixação do mesmo na pele.

A escolha do músculo gastrocnemio medial e tibial anterior se deve ao fato desses serem descritos na literatura como músculos importantes e equilíbrio do tornozelo, controlarem o choque mecânico gerado pelo movimento e estarem intimamente ligados com o surgimento de uma fratura por estresse de tíbia (MILGROM, 1985; CAVANAGH, 1990; MIZRAHI, 2000; MILGROM, 2007).

\subsection{Protocolo Experimental}

A realizaçāo do protocolo proposto, as voluntárias foram orientados a realizar os seguintes movimentos:

a) Salto Vertical não especifico e especifico da modalidade esportiva (Bloqueio e Rebote): Entendeu-se por salto vertical nảo específico da modalidade esportiva, o máximo deslocamento vertical da massa corporal através do uso da propulsāo de membros inferiores e tronco, usando como auxilio de equilíbrio os membros superiores. Para determinação da altura máxima que o voluntário será capaz de alcançar, utilizou-se protocolo de salto proposto por Smith et al, (1992), que utiliza gestos especificos do jogo para medida desta capacidade. As atletas realizaram simulaçōes do salto parado marcando com a mão o ponto mais alto possivel em uma fita métrica fixada em uma parede. Tomou-se a média da realização de três saltos. As voluntárias foram entāo orientadas a realizar três saltos verticais não especificos válidos sobre uma plataforma de força tendo como objetivo o alcance de uma bola fixa a uma altura pré-determinada através do teste de propulsão. Na tentativa de aumentar a especificidade do gesto, orientou-se que as voluntárias realizassem o salto vertical especifico da modalidade esportiva que simulava o fundamento de bloqueio (atletas de voleibol) e o fundamento de rebote (atletas de basquetebol) Foram considerados saltos válidos aqueles que o sujeito conseguiu atingir o objetivo (tocar a bola suspensa) e aterrissar com os dois pés na plataforma de força.

b) Mudança de direção ântero-posterior: Caracterizou-se como mudança de direção ântero-posterior, a inversão da trajetória de um deslocamento com direçăo horizontal e sentido anterior para um deslocamento horizontal de sentido posterior. Para alteração da trajetória do movimento se faz necessária a aplicação de uma 
força contrária ao sentido do deslocamento da massa, força essa que é aplicada por apenas um dos membros inferiores, o membro inferior que aplicou a força foi classificado como membro de transição. Para realizaçāo dessa tarefa, o sujeito foi orientado a arrancar bruscamente de uma distância auto selecionada em direção a plataforma realizando deslocamento no sentido anterior. A inversão do movimento foi realizada com o toque do membro de transição na plataforma. Foram realizadas seis mudanças de direção válidas, sendo três utilizando como membro de transição o membro inferior direito e três utilizando como membro de transição o membro inferior esquerdo. Foram considerados válidos os deslocamentos em que o membro de transição tocou o centro da plataforma de força.

c) Mudança de direção lateral: Definiu-se como mudança de direçảo lateral, a capacidade de alterar o sentido da trajetória de um deslocamento com alternància de membros inferiores, sendo este, a inversão de um deslocamento com direção horizontal e sentido lateral direito ou esquerdo para um deslocamento horizontal com sentido oposto. Para realização dessa tarefa, a voluntária foi orientada a arrancar bruscamente de uma distância auto selecionada em direção a plataforma realizando deslocamento lateral. A inversão do movimento foi realizada com o toque de um membro de transição na plataforma. Foram realizadas seis mudanças de direção válidas, sendo três utilizando como membro de transiçāo o membro inferior direito e três utilizando como membro de transição o membro inferior esquerdo. Foram considerados válidos os deslocamentos em que o membro de transiçăo tocou o centro da plataforma de força.

d) Salto horizontal especifico da modalidade esportiva (Ataque e Bandeja): Aceitou-se como salto horizontal, o gesto de corrida rápida seguido de salto e aterrissagem com os dois pés sobre a plataforma de força. Buscando a maior especificidade de se gesto, orientamos as voluntárias a realizar o movimento simulando o fundamento de ataque (atletas de voleibol e bandeja (atletas de basquetebol). Para realização dessa tarefa, o voluntário foi orientado a arrancar bruscamente de uma distância auto selecionada em direçảo a plataforma realizando deslocamento no sentido anterior, realizar o fundamento que lhe foi destinado e aterrissar com os dois pés sobre a plataforma de força. Foram considerados válidos os gestos em que o sujeito conseguiu aterrissar com os dois pés na plataforma de força. Foram realizados três saltos horizontais válidos. 


\subsection{Instrumentos de medição e parâmetros utilizados}

\subsubsection{Eletromiografia}

A aquisiçāo do sinal eletromiográfico foi realizada por intermédio do equipamento EMG 1000 (Lynx tecnologia eletrônica Ltda.). . Este equipamento amplifica, filtra e digitaliza até 28 canais de entrada analógica. Estas entradas estāo divididas em até 24 canais para sinais eletromoigráficos (12 passivos e 12 ativos) e 4 entradas para instrumentaçăo. Cada canal eletromiográfico possui um amplificador diferencial (Rejeiçāo de Modo Comum>100dB; Condiçāo: sinal senoidal 10Vpp, 60 $\mathrm{Hz}$ ) com ganho fixo de valor nominal 1000, impedância de entrada 10.000 MOhms tipico, um filtro passa alta Butterworth de $1^{\text {a }}$ ordem com freqüência de corte de $1 \mathrm{~Hz} e$ um filtro passa baixa Butterworth de $2^{a}$ ordem com freqüência de corte em $1 \mathrm{kHz}$. Os sinais devidamente amplificados e filtrados foram digitalizados por um conversor AVD de 16 bits de resolução com faixa de entrada programável. Para o presente estudo esta faixa foi programada em $+/-5 \mathrm{~V}$. Uma vez digitalizados, os sinais passam por filtros digitais passa alta Butterworth de $1^{\text {a }}$.ordem e passa baixa Butterworth de $2^{a}$.ordem selecionáveis respectivamente entre 0.01 e $50 \mathrm{~Hz}$ e entre $1000 / 500 / 300 / 200 \mathrm{~Hz}$. Para este projeto estes filtros foram programados para 20 e $500 \mathrm{~Hz}$ respectivamente.

Foram utilizados eletrodos ativos de superficie AE1010 (Lynx tecnologia eletrônica Ltda.) pré-amplificados com ganho de 20 vezes. A interface entre o eletrodo e a voluntária foi feita através de eletrodos duplos, separados a $2 \mathrm{~cm}$ de distância e pré-geleificados da marca HAL Indústria e Comércio Ltda.

A comunicaçăo com o microcomputador é feita através de interface de rede ETHERNET 10Mbits/s e suportado pelo programa AqDados 7.02 (Lynx tecnologia eletrônica Ltda.).

A taxa de amostragem é programável e a mesma para todos os canais. A maior taxa de amostragem é $4000 \mathrm{~Hz}$. Neste estudo utilizar-se-á freqüência de amostragem igual a $1000 \mathrm{~Hz}$. 


\subsubsection{Plataforma de Força}

As variáveis dinâmicas dos saltos e mudanças de direção foram mensuradas por intermédio de uma plataforma de força da marca KISTLER, modelo $9287 \mathrm{~A}$. Esta plataforma possui transdutores de força do tipo piezoelétrico localizados nos cantos da superficie de medição $(0,6 \times 0,9 \mathrm{~m})$. Os sinais obtidos pelos transdutores são enviados por intermédio de cabos $e$ interruptores a um amplificador de sinais (KISTLER AG, modelo 9865 B), programados automaticamente para obtenção dos valores das três componentes da força ( $F x, F z, F y)$.O controle sobre a aquisição, análise e armazenamento dos dados foi realizado pelo programa de funçōes BIOWARE (282A1-20).

$\mathrm{Na}$ execução das coletas utilizou-se uma freqüência de amostragem de 1 $\mathrm{kHz}$ na plataforma fixa.

\subsubsection{Procedimento para sincronização na aquisição simultânea dos dados.}

Para sincronizar a plataforma de força KISTLER com a EMG, utilizamos um sistema de sincronização desenvolvido pela Lynx Tecnologia Eletrônica LTDA. O sistema é acionado por intermédio de um trigger que envia sinais simultâneos para os sistemas em funcionamento. Para o sistema EMG 1000 é enviando um sinal pico a pico pré-programado de acordo com a faixa de entrada do CAD acionando simultaneamente a plataforma de força. A primeira amostra deste sinal pico a pico foi utilizada com identificadora do acionamento do trigger. Através do software Aqd analysis é feita uma operação de união paralela dos sinais de cada janela coletada formando um arquivo de FRS e EMG sincronizado com a mesma escala temporal.

\subsection{Variáveis investigadas}

\subsubsection{Variáveis Cinemáticas}

Para determinação da transição da fase excêntrica para a fase concêntrica durante a propulsão dos saltos verticais, de bloqueio e de rebote, uso-se como parâmetro a curva do deslocamento do centro de gravidade. Para determinação dessa curva, mensurou-se a força de reação de solo e, a partir desta, por dupla 
integração numérica (regra trapezoidal), foi calculada a curva posiçăo-tempo do centro de gravidade corporal.

\subsubsection{Variáveis Dinâmicas: Força de Reação do Solo}

A mensuração das variáveis cinéticas foi realizada de acordo com as condiçōes de movimento executado, conforme ilustraçōes abaixo:

A) Mudanças de Direçāo (deslocamento anterior e deslocamento lateral) e Saltos Horizontais (ataque e bandeja) Nessas condiçōes, o sujeito realizava o deslocamento de sua massa fora da plataforma, utilizando a mesma como ponto de transiçāo ou aterrissagem, sendo assim, foram mensuradas as variáveis: pico da força (mensurada em peso corporal (PC)), tempo para atingir o pico (mensurado em segundo (s)), o gradiente de crescimento do pico (GC) (razăo entre a força pico e o tempo para se atingir esse pico - mensurada em PC/s) e Impulso (Imp) em $50 \mathrm{~ms}$ (consiste na área sob a curva de força de reaçāo do solo do início do contato até $50 \mathrm{~ms}$ pós contato (mensurada em PC.s) a partir do momento do toque do sujeito na plataforma.

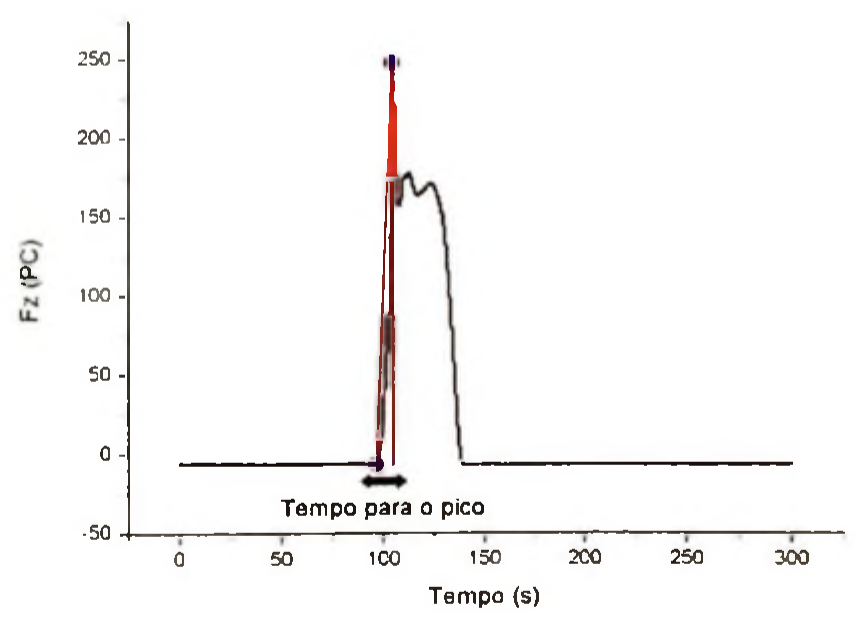

Figura 8- llustração das variáveis cinéticas mensuradas na condiçăo de saltos horizontais (ataque e bandeja).

B) Saltos Verticais (Vertical, Bloqueio e Rebote) Nessas condiçðes, o sujeito realizou tanto a propulsão quanto a aterrissagem sobre a plataforma de força, dando 
assim, condiçāo para que fossem mensuradas variáveis relacionadas ao rendimento (propulsăo do salto) e ao controle de carga(aterrissagem do salto). Dividiu-se então a análise em dois momentos, propulsão e aterrissagem, sendo mensurados nesses momentos:

1- Propulsăo - Pico de propulsăo (mensurada em peso corporal (PC)), tempo para atingir o pico de impulso (mensurado em segundo (s)), GC do pico de impulso (mensurada em PC/s) e Impulso em $50 \mathrm{~ms}$ a partir da fase concêntrica do movimento.

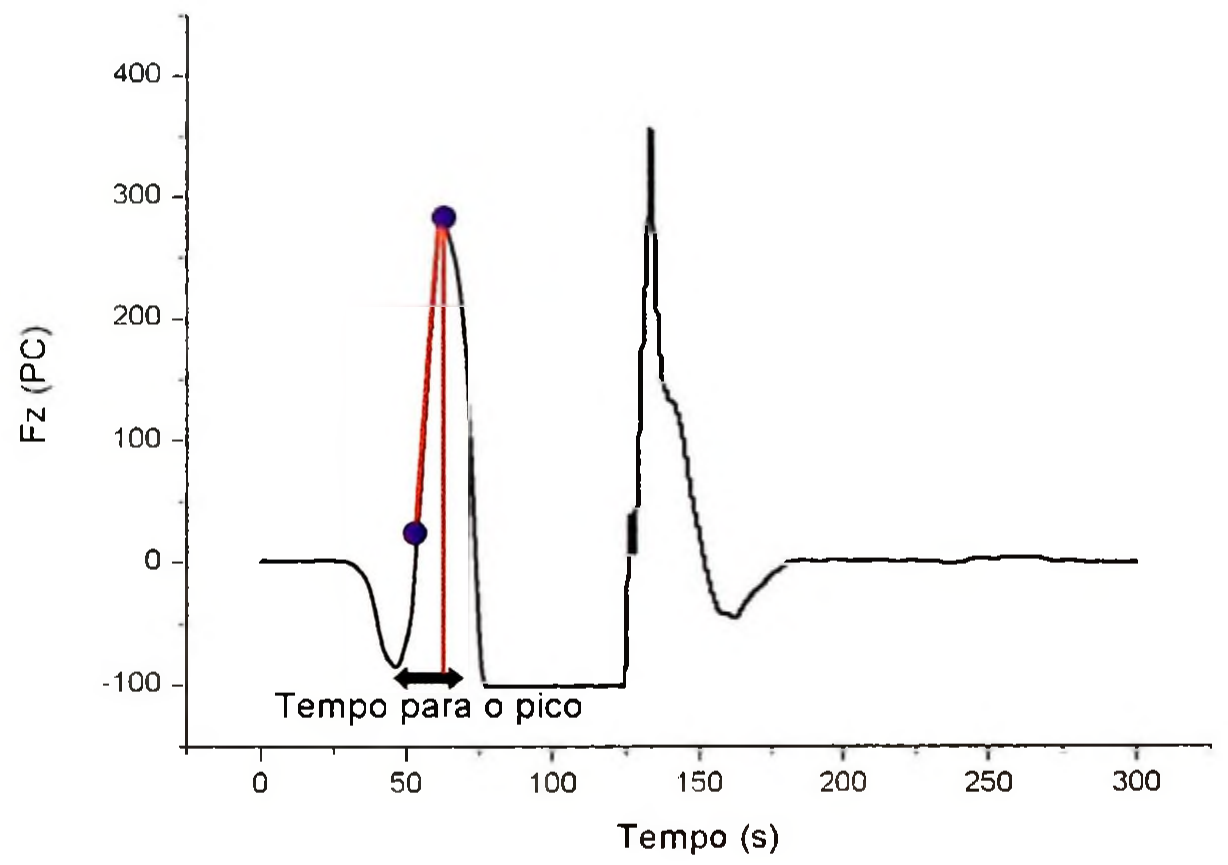

Figura 9- llustração das variáveis cinéticas mensuradas na condiçăo de saltos verticais (vertical, bloqueio e bandeja) no momento de impulso.

2- Aterrissagem do Salto - Pico de propulsăo (mensurada em peso corporal $(P C)$ ), tempo para atingir o pico de impulso (mensurado em segundo (s)), GC do pico de impulso (mensurada em $\mathrm{PC} / \mathrm{s}$ ) e Impulso em $50 \mathrm{~ms}$ a partir do toque do pé na 
plataforma na fase de aterrissagem do salto. Durante a análise de dados, observouse que a maioria dos sujeitos apresentava a formação de um vale no ponto intermediário da reta entre o toque na plataforma e o primeiro pico de força. $O$ presente fenômeno promoveu a criação de um pico intermediário entre o toque do pé e o pico da força, dividindo essa reta em duas partes separadas por um vale de transição. Para os atletas que apresentaram essa característica de curva, foram calculados o pico de força que então foi chamado de o pico intermediário entre o toque do pé e o pico de força intitulado aqui como Pico i. Como o vale de transição pode ser um grande indicativo do quão harmônica foi a transição da carga do antepé ao retropé na aterrissagem do salto, calculou-se também a área desse vale ao qual foi denominada impulso do vale.
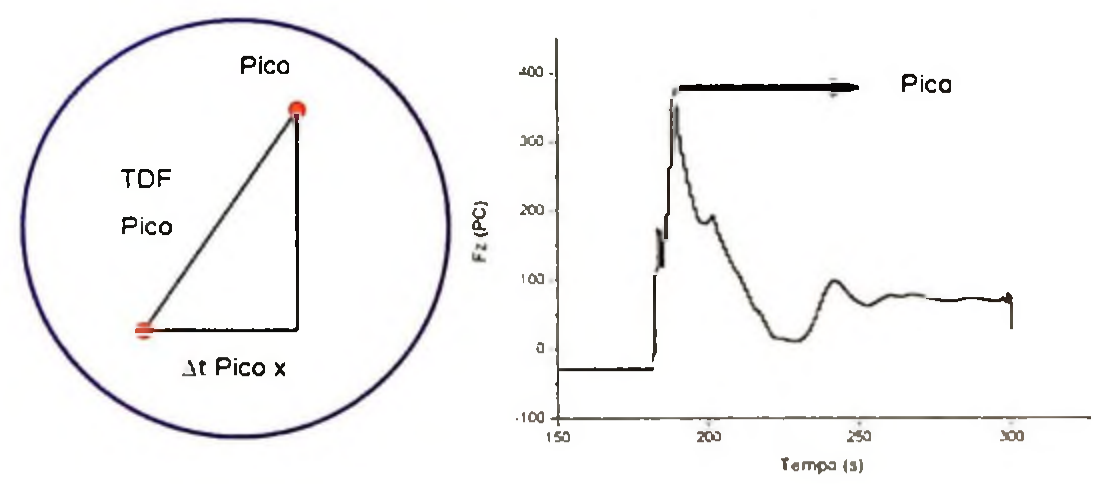

Figura 10 - llustração das variáveis cinéticas mensuradas na condiçăo de saltos horizontais (ataque e bandeja) no momento de aterrissagem.

\subsubsection{Variáveis Eletromiográficas}

Para determinação da intensidade da ação muscular nas aterrissagens dos saltos e mudança de direção, foi calculado o RMS 50 ms pré e 50 ms pós contato do pé com o solo.

A determinação do tempo de $50 \mathrm{~ms}$ pré - Contato para o corte e cálculo do RMS foi baseado na condição de que, a oscilação de uma corrida rápida é inferior a 
$200 \mathrm{~ms}$ e o que consiste no intervalo de $30 \%$ a $100 \%$ do ciclo da corrida (NOVACHECK, 1998). A atividade do músculo Tibial Anterior que investigada no presente estudo se dá no intervalo de 40 até $100 \%$ do ciclo da fase de oscilação. Nesse intervalo, de 40 a $90 \%$, sua atividade mantém o posicionamento do pé e impede que o mesmo arraste no chão e de 90 a $100 \%$, sua atividade corresponde a uma ação antecipatória que objetiva preparar a articulação do tornozelo e o membro inferior para receber o choque de contato com o solo (CAVANAGH, 1990). Sendo $70 \%$ do ciclo da corrida correspondente a aproximadamente $200 \mathrm{~ms}, 10 \%$ desse ciclo corresponde a não mais do que $30 \mathrm{~ms}$. Portanto, qualquer atividade do Tibial anterior que anteceda o toque do pé no chão nos movimentos estudados, em um periodo maior do que $50 \mathrm{~ms}$ pode estar associada ao controle do posicionamento do pé e não o controle da carga. Outra evidência literária usada para determinação desse periodo foi de que a pré-ativação muscular que prepara o aparelho locomotor para uma tarefa onde serão realizados movimentos corresponde a cerca de $50 \mathrm{~ms}$ (HODGES \& RICHARDSON, 1999).

A investigaçāo da RMS do sinal eletromiográfico, justifica-se pelo fato de que a fase de apoio do ciclo da corrida rápida é inferior a $100 \mathrm{~ms}$ e corresponde ao intervalo de 0 a $30 \%$ ciclo (NOVACHECK, 1997). Sendo o Tibial Anterior ativo no intervalo de 0 a $20 \%$ (CAVANAGH, 1990). Uma vez que $30 \%$ do ciclo correspondente a $100 \mathrm{~ms}, 20 \%$ do ciclo corresponde a aproximadamente $50 \mathrm{~ms}$.

Embora o gesto seja completamente diferente, no movimento de salto, o pico de salto horizontal e vertical de magnitudes semelhantes aos investigados no presente estudo não excedem 10ms após o contato com o solo (AMADIO, 1989). Tornando assim desnecessária a investigação da ação muscular após 50ms. 

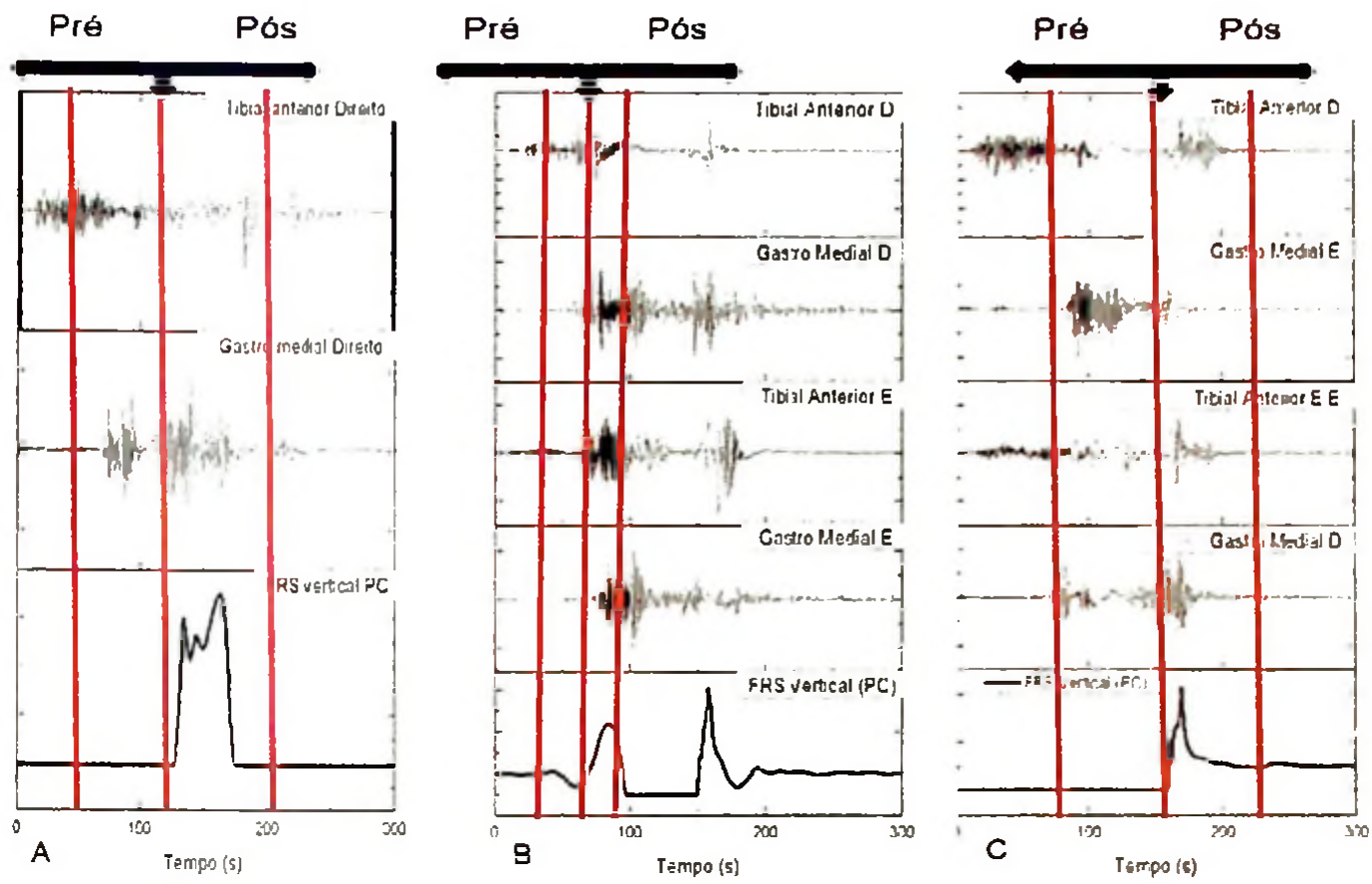

Figura 11: llustração dos parâmetros utilizados para determinaçăo da intensidade da atividade muscular RMS pré e pós-contato nas condições A - deslocamentos anterior e lateral, B saltos vertical, bloqueio e rebote e $\mathrm{C}$ - saltos horizontais (ataque e bandeja).

\subsection{Critérios para a composição dos grupos}

Para formação dos grupos experimental e controle, foram adotados os seguintes critérios:

Parâmetros Eletromiográficos - Foram considerados os parâmetros eletromiográficos supracitados sem diferenciaçảo entre membro direito e esquerdo no grupo controle, sendo no grupo experimental, analisados os parâmetros apenas dos membros acometidos pela patologia. Ex.: Sujeito 1 foi monitorado por EMG de superficie em todas as condições do protocolo nos músculos Tibial Anterior direito e esquerdo e Gastrocnemio Medial direito e esquerdo, sendo enquadrado no grupo controle. Sujeito 2, realizou os mesmos procedimentos e foi enquadrado no grupo experimental por possuir histórico de fratura por estresse em Tíbia direita. Sujeito 3 , 
realizou os mesmos procedimentos e foi enquadrado no grupo experimental por possuir histórico de fratura por estresse em Tíbia esquerda. Sujeito 4 , realizou os mesmos procedimentos e foi enquadrado no grupo experimental por possuir histórico de fratura por estresse em Tíbia bilateral. Para formação dos grupos e processamento estatísco dos dados, foram adotados os seguintes critérios:

Nas condiçōes onde os parâmetros analisados envolviam bilateralidade de membros inferiores (salto vertical, salto de ataque/bandeja e salto de bloqueio/rebote) o RMS dos músculos Tibial anterior direito e esquerdo e Gastrocnemio medial direito e esquerdo foram tratados através da estatística descritiva para o cálculo da média e do desvio padrão e formaram o conjunto Tibial anterior controle e Gastrocnemio medial controle, não sendo diferidos em direito e esquerdo. Sendo assim, o Sujeito 1 e em todos os sujeitos que se enquadraram nesse grupo, formaram os resultados de média e desvio padrāo do RMS para Tibial anterior e Gastrocnemio medial. Já os sujeitos 2, 3 e 4, assim como todos que constituiram o grupo experimental, foram planificados apenas por seus membros acometidos. Na média do RMS de Tibial anterior, foram registrados os dados do membro inferior direito do Sujeito 2, membro inferior esquerdo do sujeito 3 e dos membros inferiores direito e esquerdo do sujeito 4 , formando assim uma média e desvio padrão do RMS de Tibial anterior e Gastrocnemio medial apenas em membros que apresentaram Fratura por estresse. Dessa forma, pode-se comparar membros saudáveis com membros acometidos.

Nas condições de unilateralidade de gesto (deslocamentos anterior e lateral) foram mensurados os valores RMS apenas do membro de transição tanto para o grupo controle quanto para o grupo experimental. Nesse caso, na condiçảo deslocamento anterior direito (membro direito usado como apoio para transiçăo da massa de um deslocamento anterior para um deslocamento posterior) os Sujeitos 1, 2 e 4 tiveram o RMS da perna esquerda descartado, já o sujeito 2 teve o RMS de ambas as pernas descartado.

Parâmetros de Forca - Na planificaçảo para aplicaçăo do tratamento estatístico e cálculo da média e desvio padrão, foram descartados apenas os parâmetros de força do membro não acometido das atletas do grupo controle durante gestos unilaterais em que esses não foram usados como membro de transiçăo na mudança da trajetória da massa. Ex.: Sujeito 2 teve descartadas as 3 execuçōes das condiçōes deslocamento anterior esquerdo e deslocamento lateral 
esquerdo, Sujeito 3 teve descartadas as 3 execuçǒes das condiçǒes deslocamento anterior direito e deslocamento lateral direito e o Sujeito 4 não teve nenhuma condição descartada.

3.9 Análise e tratamento dos dados

\subsubsection{Procedimentos matemáticos}

Os dados referentes a Força de Reação do Solo e eletromiografia durante os saltos e deslocamentos foram processados e calculados por intermédio de rotinas matemáticas elaboradas no programa Matlab (versão 7.0 .4 (R2007a), Mathworks, Inc. e Origin (versāo 8.0, Microcal Software, Inc. O sinal eletromiográfico foi retificado através da retificação de onda cheia e normalizado pela média da curva.

\subsubsection{Tratamento estatistico dos dados}

Para testar a normalidade dos dados, foi aplicado o teste de KOLMOGOROVSMIRNOV. Os dados que apresentaram normalidade foram processados utilizando-se o teste t Student e então seguiu-se a comparação dos grupos experimental e controle pela estatistica descritiva (média e desvio padrāo). Dados que não apresentaram normalidade da amostra foram processados através do teste $U$ Man-Whitney e entăo a estatistica descritiva (média e desvio) padrăo para a comparação dos grupos. Em ambas as situações utilizou-se um valor alfa de $95 \%(p \leq 0,05)$. 


\section{RESULTADOS}

\subsection{Variáveis dinâmicas: força de reação do solo}

Para uma melhor apresentação dos resultados, as variáveis dinâmicas analisadas foram organizadas nas Tabelas de 2 a 6 . Destaca-se a importância dessas informaçōes na caracterização da condição investigada e na diferenciaçảo da geração e controle das cargas externas entre os grupos com histórico de fratura por estresse (experimental) e controle.

Para a condição de deslocamento anterior (Tabela 2), as variáveis Pico $(p=0,455)$ e Imp50ms $(p=0,177)$ não apresentaram diferença significativa entre os grupos estudados. Porém, observa-se no grupo experimental, uma diferença estatisticamente significativa nas variáveis Tempo Pico $(p=0,05)$ e GC $(p=0,05)$. A primeira delas foi $25 \%$ menor, e a segunda $63 \%$ maior no grupo experimental quando comparadas ao grupo controle.

Tabela 2 - Média e desvio padrăo de parâmetros relacionados à componente vertical da Força de Reaçăo do Solo para os grupo controle e com histórico de Fratura por Estresse (FE) na condiçăo de deslocamento anterior. Onde $\left(^{\circ}\right)$ indica diferença significativa $(p \geq 0,05)$ entre os grupos estudados.

\begin{tabular}{lll}
\hline Força pico (PC) & $1,78 \pm 0,20$ & $1,87 \pm 0,46$ \\
Tempo para o pico (s) & $0,20 \pm 0,09$ & $0,15 \pm 0,09\left(^{*}\right)$ \\
GC (PC/s) & $12,63 \pm 10,04$ & $20,7 \pm 18,31\left(^{*}\right)$ \\
Impulso aos 50ms (PC.s) & $29,95 \pm 10,88$ & $27,0 \pm 14,84$ \\
\hline
\end{tabular}




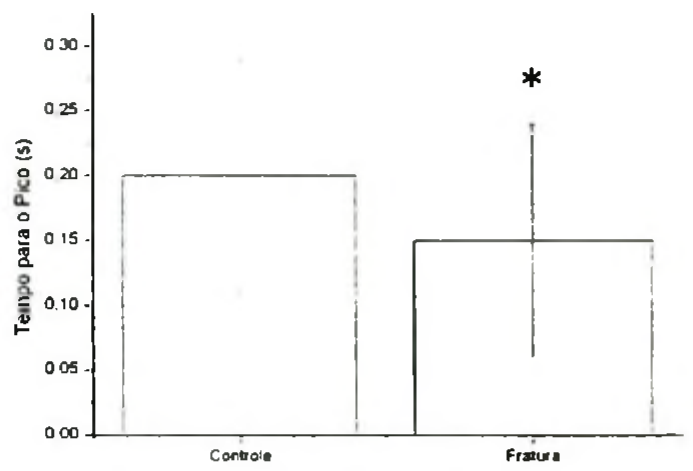

Figura 12- Média e desvio padrăo do tempo para o pico relacionado à componente vertical da Força de Reação do Solo para os grupos controle e com histórico de Fratura por Estresse (FE) na condição de deslocamento anterior. Onde $\left(^{*}\right)$ indica diferença significativa $(p \geq 0,05)$ entre os grupos estudados.

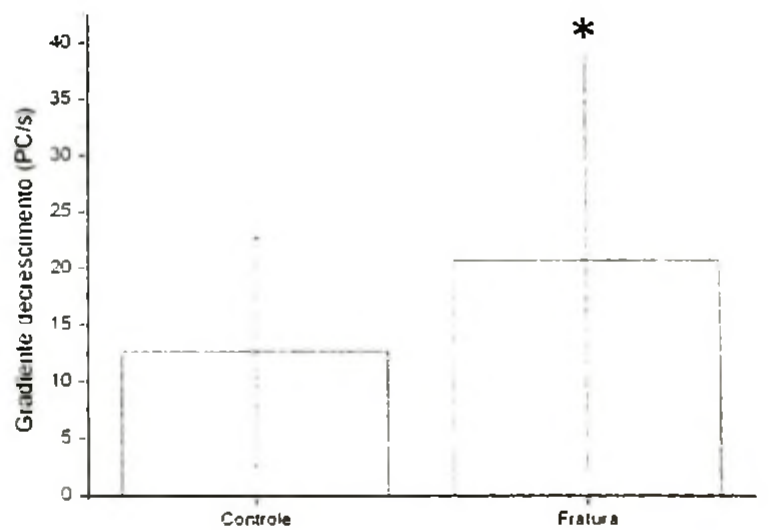

Figura 13- Média e desvio padrāo do GC relacionados à componente vertical da Força de Reação do Solo para os grupos controle e com histórico de Fratura por Estresse (FE) na condição de deslocamento anterior. Onde $\left(^{*}\right)$ indica diferença significativa $(p \geq 0,05)$ entre os grupos estudados.

Durante a realização dos deslocamentos laterais (Tabela 3), foram encontradas diferenças estatisticamente significativas nas variáveis tempo de pico $(p=0,02)$ que foi maior no grupo experimental) e $\operatorname{Imp} 50(p=0,001)$ (menor no grupo experimental), notando-se um processo inverso ao deslocamento anterior. As variáveis pico $(p=0,389)$ e GC $(307)$ năo apresentaram diferença entre os grupos. 
Tabela 3 - Média e desvio padrão de parâmetros relacionados à Força de Reaçăo do Solo para os grupo controle e com histórico de Fratura por Estresse na condição de deslocamento lateral. Onde (") indica diferença significativa $(p \geq 0,05)$ entre os grupos estudados.

\begin{tabular}{lll}
\hline & Grupo Controle $(n=33)$ & Histórico de FE $(n=51)$ \\
\hline Força pico (PC) & $1,98 \pm 0,36$ & $2,09 \pm 0,40$ \\
Tempo para o pico(s) & $0,10 \pm 0,05$ & $0,13 \pm 0,10\left(^{*}\right)$ \\
GC (PC/s) & $23,79 \pm 11,48$ & $20,84 \pm 8,74$ \\
Impulso aos 50ms (PC.s) & $25,23 \pm 8,61$ & $17,90 \pm 4,49\left({ }^{*}\right)$ \\
\hline
\end{tabular}

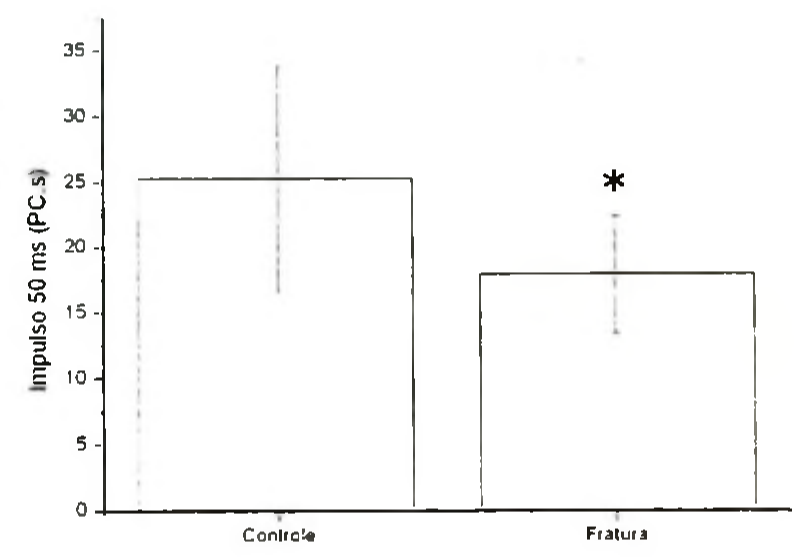

Figura 14- Média e desvio padrão do Impulso aos $50 \mathrm{~ms}$ relacionados à Força de Reação do Solo para os grupo controle e com histórico de Fratura por Estresse na condiçăo de deslocamento lateral. Onde $\left(^{*}\right)$ indica diferença significativa $(p \geq 0.05)$ entre os grupos estudados. 


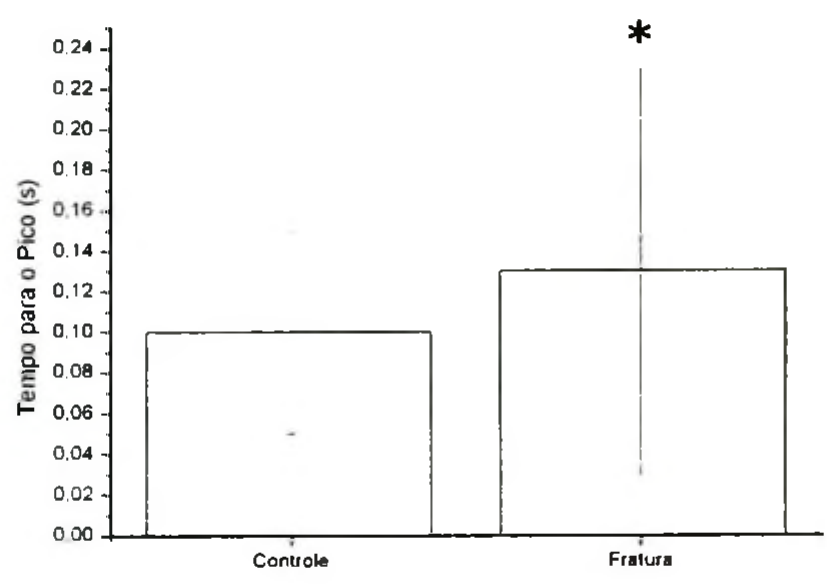

Figura 15- Média e desvio padrăo do tempo para pico relacionados à Força de Reaçăo do Solo para os grupo controle e com histórico de Fratura por Estresse na condiçăo de deslocamento lateral. Onde (*) indica diferença significativa $(p \geq 0,05)$ entre os grupos estudados.

Para os movimentos específicos, nos quais as voluntárias praticantes de basquete realizaram a bandeja e as voluntárias praticantes de voleibol executaram o ataque (Tabela 4), nāo foi observada nenhuma alteração estatisticamente significativa entre os grupos experimental e controle em nenhuma das variáveis dinâmicas estudadas.

Tabela 4- Média e desvio padrăo de paràmetros relacionados à Força de Reaçăo do Solo para os grupos controle e com histórico de Fratura por Estresse nos saltos especificos (bandeja e ataque) para cada uma das modalidades. Onde ( $\left(^{*}\right)$ indica diferença significativa $(p \geq 0,05)$ entre os grupos estudados.

\begin{tabular}{lll}
\hline & Grupo Controle $(n=46)$ & Histórico de $F E(n=37)$ \\
\hline Força pico (PC) & $3,98 \pm 0,76$ & $3,85 \pm 0,54$ \\
Tempo para o pico(s) & $0,06 \pm 0,016$ & $0,06 \pm 0,01$ \\
GC(PC/s) & $63,19 \pm 26,55$ & $59,84 \pm 17,37$ \\
Imp aos 50ms(PC.s) & $76,04 \pm 18,33$ & $69,79 \pm 14,03$ \\
\hline
\end{tabular}

Ainda para os saltos especificos foram utilizados deslocamentos predominantemente verticais que simulavam os gestos de bloqueio (voluntárias praticantes de voleibol) e de rebote (voluntárias praticantes de basquetebol). Os 
resultados (Tabela 5), năo evidenciaram nenhuma diferença entre os grupos para as variáveis força pico $(p=0,944)$, tempo para pico $(p=0,753)$ e $G C(p=0,521)$. Neste movimento, observou-se que alguns dos voluntários apresentavam um pico inicial (pico transitório), de menor intensidade do que o pico principal, cuja manifestaçăo deriva do primeiro contato do pé com o solo. Embora caracterizado por uma diferença estatistica significativa $(p=0,012)$, o tempo menor de desenvolvimento $(3,6 \%)$ no grupo experimental para o pico transitório (pico i) năo gerou interferência no GC do pico i nesse grupo. A não interferência ocorreu pelo fato do grupo controle ter apresentado para esse pico uma força maior. A associação desses fatos, fez com que a inclinação desse pico fosse significativamente $(p=0,014)$ menor no grupo experimental (GC 16,9\%).

Tabela 5 - Média e desvio padrão de parâmetros relacionados à Força de Reação do Solo para os grupo controle e com histórico de Fratura por Estresse nos saltos especificos predominantemente verticais (bloqueio ou rebote). Onde $\left(^{*}\right)$ indica diferença significativa $(p \geq 0,05)$ entre os grupos estudados.

\begin{tabular}{lll}
\hline & Grupo Controle (n=51) & Histórico de FE (n=38) \\
\hline Pico de propulsão (PC) & $1,54 \pm 0,49$ & $1,47 \pm 0,38$ \\
Tempo para o pico propulsão $(\mathrm{s})$ & $0,08 \pm 0,07$ & $0,07 \pm 0,06$ \\
GC (PC/s) & $3,56 \pm 4,17$ & $2,21 \pm 2,14$ \\
Impulso de Propulsão aos 50ms (PC/s) & $66,53 \pm 25,21$ & $66,53 \pm 20,98$ \\
\hline Pico de aterrissagem (PC) & $2,49 \pm 1,11$ & $2,69 \pm 0,94$ \\
Tempo para o pico de aterrissagem (s) & $0,05 \pm 0,02$ & $0,05 \pm 0,01$ \\
GC p p0,05 na aterrissagem (PC/s) & $45,46 \pm 30,14$ & $50,4 \pm 29,12$ \\
Impulso (50ms) na aterrissagem (PC/s) & $6,62 \pm 13,75$ & $1,26 \pm 8,95$ \\
\hline
\end{tabular}

Analisando-se a condição de salto vertical sem a especificidade esportiva (Tabela 6), observou-se diferença estatisticamente significativa $(p=0,04)$ apenas para o impulso calculado nos primeiros $50 \mathrm{~ms}$ após a aterrissagem. Este foi $158,3 \%$ mais baixo no grupo experimental em relação ao grupo controle 
Tabela 6 Média e desvio padrão de parâmetros relacionados à Força de Reaçăo do Solo para os grupo controle e com histórico de Fratura por Estresse na condição de salto vertical. Onde (*) indica diferença significativa $(p \geq 0,05)$ entre os grupos estudados.

\begin{tabular}{lll}
\hline & Grupo Controle $(n=51)$ & Histórico de FE $(n=38)$ \\
\hline Pico de propulsão(PC) & $1,46 \pm 0,48$ & $1,49 \pm 0,35$ \\
Tempo para o pico de propulsāo (s) & $0,07 \pm 0,07$ & $0,04 \pm 0,04$ \\
GC(PC/s) & $2,71 \pm 4,04$ & $2,27 \pm 2,26$ \\
Impulso de Propulsão aos 50ms(PC/s) & $66,83 \pm 25,02$ & $69,6 \pm 19,57$ \\
Pico de aterrissagem (PC) & $2,29 \pm 1,19$ & $2,46 \pm 1,21$ \\
Tempo para o pico de aterrissagem (s) & $0,05 \pm 0,02$ & $0,05 \pm 0,02$ \\
GC na aterrissagem (PC/s) & $39,21 \pm 35,34$ & $47,06 \pm 37,59$ \\
Impulso (50ms) na aterrissagem (PC/s) & $6,44 \pm 13,91$ & $-3,76 \pm 10,83\left(^{\circ}\right)$ \\
\hline
\end{tabular}

\subsection{Variáveis eletromiográgicas}

Após a caracterização das forças externas atuantes nos movimentos relacionados no protocolo de coleta, as Tabelas de 7 a 11 apresentam os resultados da atividade eletromiográfica dos músculos gastrocnemio medial e tibial anterior, registradas de forma sincronizada durante a coleta de dados.

O sinal eletromiográfico foi mensurado a partir do toque do pé no solo, em um intervalo $50 \mathrm{~ms}$ antes e $50 \mathrm{~ms}$ após o contato, do pé com o solo nas condiçōes de deslocamento anterior e deslocamento lateral. O mesmo procedimento de registro do sinal eletromiográfico foi feito no momento de propulsão do salto, porém, para esse momento, tomou-se como parâmetro o inicio da fase concêntrica após o contra-movimento. O calculo do RMS nas fases supracitadas, serviu como parâmetro para comparação da intensidade da atividade muscular entre os grupos. 
Tabela 7- Média e desvio padrăo do RMS (u.a.) para os músculos Gastrocnemio Medial (GM) e Tibial anterior (TA) para o grupo controle e o grupo com histórico de Fratura por Estresse na condiçăo de deslocamento anterior. Onde (") indica diferença significativa $(p \geq 0,05)$ entre os grupos estudados.

\begin{tabular}{llllc}
\hline & \multicolumn{2}{c}{ Grupo Controle $(n=100)$} & \multicolumn{2}{c}{ Histórico de FE $(n=55)$} \\
& GM & TA & GM & TA \\
\hline $\begin{array}{l}\text { Atividade muscular } \\
\text { pré-contato }\end{array}$ & $1,19 \pm 0,84$ & $1,70 \pm 1,07$ & $1,43 \pm 0,62\left(^{*}\right)$ & $1,32 \pm 0,75$ \\
$\begin{array}{l}\text { Atividade muscular } \\
\text { pós-contato }\end{array}$ & $1,19 \pm 0,68$ & $1,79 \pm 0,92$ & $1,14 \pm 0,38$ & $1,70 \pm 0,80$ \\
\hline
\end{tabular}

Avaliando os resultados para as fase de pré e pós contato do pé com o solo na condição de deslocamento anterior (Tabela 7), nota-se que o músculo Gastrocnemio Medial, apresentou no grupo experimental, uma atividade 10,9\% maior $(p=0,024)$ de na fase que antecede o contato com o solo. Na fase pós-contato, a diferença na intensidade de contração dos músculos Tibial Anterior e Gastrocnemio Medial não foi estatisticamente significativa entre os grupos.

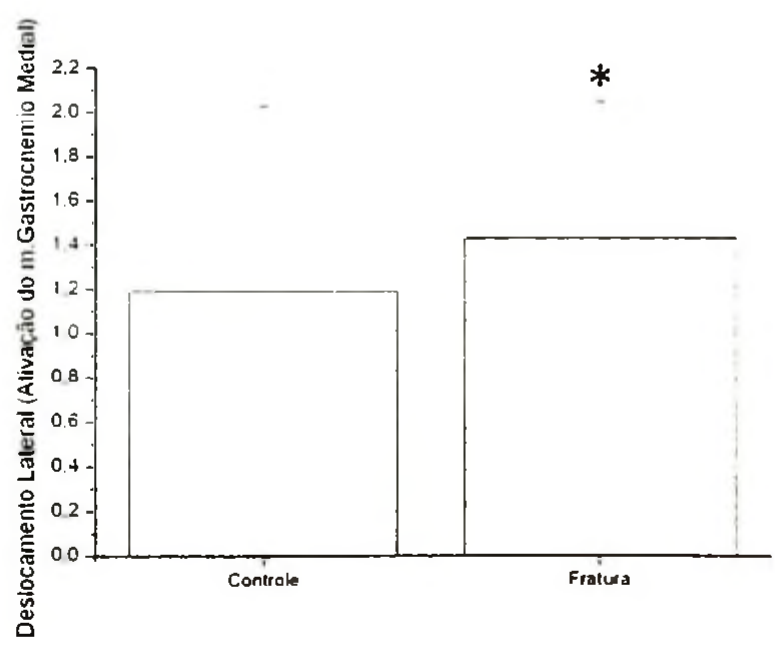

Figura 16- Média e desvio padrăo do RMS (u.a.) para o músculos Gastrocnêmio Medial (GM) em $50 \mathrm{~ms}$ pré-contato para o grupo controle e o grupo com histórico de Fratura por Estresse na condiçăo de deslocamento anterior. Onde $\left(^{(*)}\right.$ indica diferença significativa $(p \geq 0,05)$ entre os grupos estudados. 
Tabela 8 - Média e desvio padrăo do RMS (u.a.) para os músculos Gastrocnemio Medial (GM) e Tibial Anterior (TA) para o grupo controle e o grupo com histórico de Fratura por Estresse na condiçăo de deslocamento lateral. Onde (") indica diferença significativa $(p \geq 0,05)$ entre os grupos estudados.

\begin{tabular}{lllll}
\hline & \multicolumn{2}{l}{ Grupo Controle $(n=101)$} & \multicolumn{2}{l}{ Histórico de FE $(n=66)$} \\
& GM & TA & GM & TA \\
\hline $\begin{array}{l}\text { Atividade muscular } \\
\text { pré-contato }\end{array}$ & $1,23 \pm 0,57$ & $1,04 \pm 0,68$ & $1,32 \pm 0,56$ & $1,09 \pm 1,01$ \\
$\begin{array}{l}\text { Atividade muscular } \\
\text { pós-contato }\end{array}$ & $1,11 \pm 0,67$ & $1,27 \pm 0,66$ & $1,19 \pm 0,41$ & $1,22 \pm 0,71$ \\
\hline
\end{tabular}

Para o deslocamento lateral (Tabela 8), tanto na fase de pré quanto na fase de pós-contato, nenhuma diferença estatisticamente significativa entre os grupos foi encontrada quando da análise da intensidade de ativaçăo muscular.

Tabela 9. Média e desvio padrāo do RMS (u.a.) para os músculos Gastrocnemio Medial (GM) e Tibial Anterior (TA) para o grupo controle e o grupo com histórico de Fratura por Estresse na condição de ataque ou bandeja. Onde $\left(^{(*)}\right.$ indica diferença significativa $(p \geq 0,05)$ entre os grupos estudados.

\begin{tabular}{llclc}
\hline & \multicolumn{2}{l}{ Grupo Controle $(n=92)$} & \multicolumn{2}{l}{ Histórico de FE $(n=37)$} \\
& GM & TA & GM & TA \\
\hline $\begin{array}{l}\text { Atividade muscular pré- } \\
\text { contato }\end{array}$ & $\mathbf{4}, 23 \pm 2,97$ & $1,46 \pm 1,42$ & $4,25 \pm 2,48$ & $1,47 \pm 1,32$ \\
$\begin{array}{l}\text { Atividade muscular pós- } \\
\text { contato }\end{array}$ & $3,44 \pm 1,96$ & $2,04 \pm 1,66$ & $3,18 \pm 1,98$ & $2,94 \pm 2,0\left(^{*}\right)$ \\
\hline
\end{tabular}

Para a condição de salto horizontal especifico (Tabela 9), o grupo experimental apresentou uma maior atividade do músculo Tibial Anterior na fase de pós-contato $(44,1 \%)$ quando comparado ao grupo controle, mostrando assim uma diferença estatisticamente significativa $(p=0,02)$ entre eles. Não foram observadas diferenças significativas entre os grupos para os músculos Tibial Anterior e Gastrocnemio Medial quando da análise do RMS nos $50 \mathrm{~ms}$ que antecederam o momento do toque do pé no solo, condição que evidencia um padrão de preparação 
antecipatória à carga semelhante ao observado para o grupo controle.

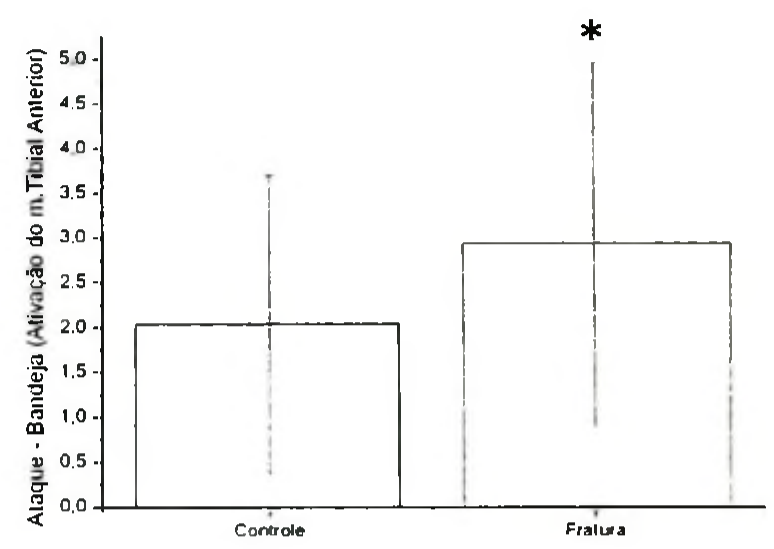

Figura17- Média e desvio padrão do RMS (u.a.) para o músculo Tibial Anterior (TA) em $50 \mathrm{~ms}$ pós contato para o grupo controle e o grupo com histórico de Fratura por Estresse na condição de ataque ou bandeja. Onde (*) indica diferença significativa $(p \geq 0,05)$ entre os grupos estudados.

Tabela 10 - Média e desvio padrāo do RMS (u.a.) para os músculos Gastrocnemio Medial (GM) e Tibial Anterior (TA) para o grupo controle e o grupo com histórico de Fratura por Estresse na condiçāo de bloqueio/rebote. Onde (") indica diferença significativa $(p \geq 0,05)$ entre os grupos estudados

\begin{tabular}{|c|c|c|c|c|}
\hline & \multicolumn{2}{|c|}{ Grupo Controle $(n=102)$} & \multicolumn{2}{|c|}{ Histórico de FE $(n=38)$} \\
\hline & GM & TA & GM & TA \\
\hline Atividade muscular pré-contato & $1,82 \pm 1,25$ & $2,23 \pm 1,72$ & $1,86 \pm 0,81$ & $1,41 \pm 1,02\left(^{*}\right)$ \\
\hline Atividade muscular pós-contato & $2,33 \pm 1,36$ & $1,97 \pm 1,66$ & $2,17 \pm 1,01$ & $1,42 \pm 1,04$ \\
\hline Atividade muscular pré-contato & $2,39 \pm 1,19$ & $0,97 \pm 0,78$ & $2,07 \pm 0,81$ & $0,98 \pm 0,65$ \\
\hline Atividade muscular pós-contato & $2,29 \pm 1,17$ & $1,63 \pm 1,14$ & $1,95 \pm 0,80$ & $1,90 \pm 0,97$ \\
\hline
\end{tabular}

Para o grupo experimental, durante a propulsăo do salto vertical específico do esporte, a atividade muscular pré-contato que é caracterizada como $50 \mathrm{~ms}$ que antecedem o inicio da fase concêntrica do movimento, apresentou uma diminuiçăo de $36 \%$ do valor RMS para o músculo tibial anterior em relaçăo ao grupo controle apresentando assim uma diferença estatisticamente significativa $(p=0,024)$. Na atividade muscular pós-contato de impulso, (50 $\mathrm{ms}$ após o início da fase concêntrica), pré-contato de aterrissagem e pós-contato de aterrissagem, nenhuma 
diferença significativa $(p \geq 0,05)$ foi encontrada no valor RMS entre os grupos para os músculos estudados.

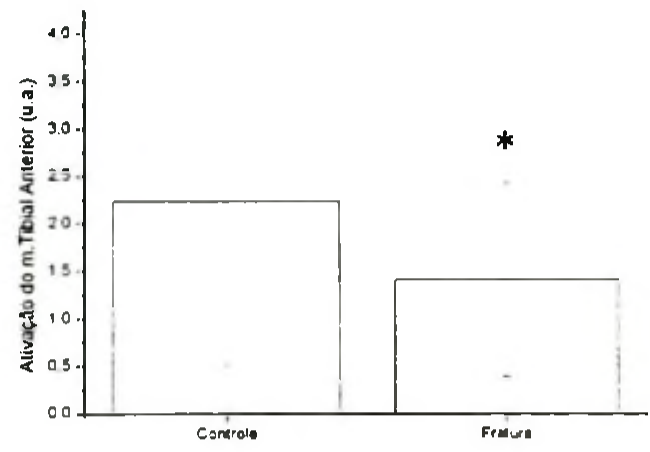

Figura 18- Média e desvio padrăo do RMS (u.a.) para o músculo Tibial Anterior (TA) em $50 \mathrm{~ms}$ précontato da fase de propulsão para o grupo controle e o grupo com histórico de Fratura por Estresse na condiçăo de bloqueio/rebote. Onde (*) indica diferença significativa $(p \geq 0,05)$ entre os grupos estudados

Para o salto vertical (Tabela 11), foram encontradas diferenças estatisticamente significativas no valor RMS para o músculo Tibial Anterior. No grupo experimental, o valor RMS deste o músculo foi significativamente menor em todas as condiçōes avaliadas (pré-impulso $32,2 \%(p=0,002)$, pós-impulso $31 \%(p=0,012)$, préaterrissagem $16,6 \%(p=0,023)$ e pós-aterrissagem $19 \%(p=0,026)$. No momento pósaterrissagem, o músculo Gastrocnemio Medial também apresentou um valor RMS diminuido no grupo experimental $(14,1 \%)$. Nảo foram observadas diferenças estaticamente significativas $(p \geq 0,05)$ entre os grupos para o músculo Gastrocnemio Medial no momento de propulsão (fases pré- contato e pós-contato) e no momento de pré-contato da fase de aterrissagem. 
Tabela 11- Média e desvio padrăo do RMS (u.a.) para os músculos Gastrocnemio Medial (GM) e Tibial Anterior (TA) para o grupo controle e o grupo com histórico de Fratura por Estresse na condiçăo de salto vertical. Onde $\left(^{*}\right)$ indica diferença significativa $(p \geq 0,05)$ entre os grupos estudados.

\begin{tabular}{|c|c|c|c|c|}
\hline & \multicolumn{2}{|c|}{ Grupo Controle $(n=102)$} & \multicolumn{2}{|c|}{ Histórico de FE $(n=38)$} \\
\hline & GM & TA & GM & TA \\
\hline $\begin{array}{l}\text { Atividade muscular pré- } \\
\text { contato na fase de propulsăo }\end{array}$ & $1,63 \pm 1,14$ & $2,11 \pm 1,65$ & $1,93 \pm 0,81$ & $1,43 \pm 0,97\left(\left(^{*}\right)\right.$ \\
\hline 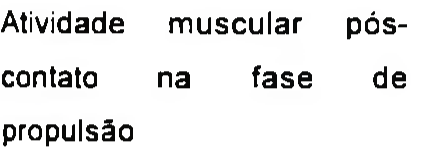 & $2,12 \pm 1,31$ & $2,06 \pm 1,63$ & $2,67 \pm 1,20$ & $1,42 \pm 0,82\left(^{*}\right)$ \\
\hline $\begin{array}{l}\text { Atividade muscular pré- } \\
\text { contato na fase de } \\
\text { aterrissagem }\end{array}$ & $2,28 \pm 1,05$ & $0,96 \pm 0,65$ & $2,39 \pm 1,11$ & $0,80 \pm 0,60\left(\left(^{*}\right)\right.$ \\
\hline $\begin{array}{l}\text { Atividade muscular pós- } \\
\text { contato na fase de } \\
\text { aterrissagem }\end{array}$ & $2,41 \pm 1,22$ & $1,52 \pm 0,95$ & $2,07 \pm 0,60^{*}$ & $1,23 \pm 0,62\left(^{*}\right)$ \\
\hline
\end{tabular}

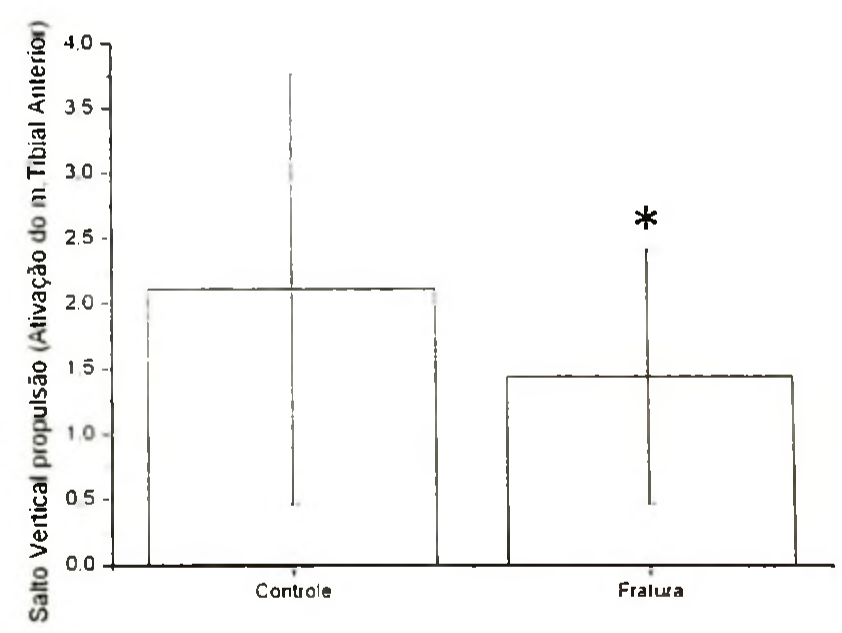

Figura19- Média e desvio padrão do RMS (U.a.) para o músculo Tibial Anterior (TA) no momento $50 \mathrm{~ms}$ pré-contato de propulsão para o grupo controle e o grupo com histórico de Fratura por Estresse na condiçăo de salto vertical. Onde (") indica diferença significativa $(p \geq 0,05)$ entre os grupos estudados. 


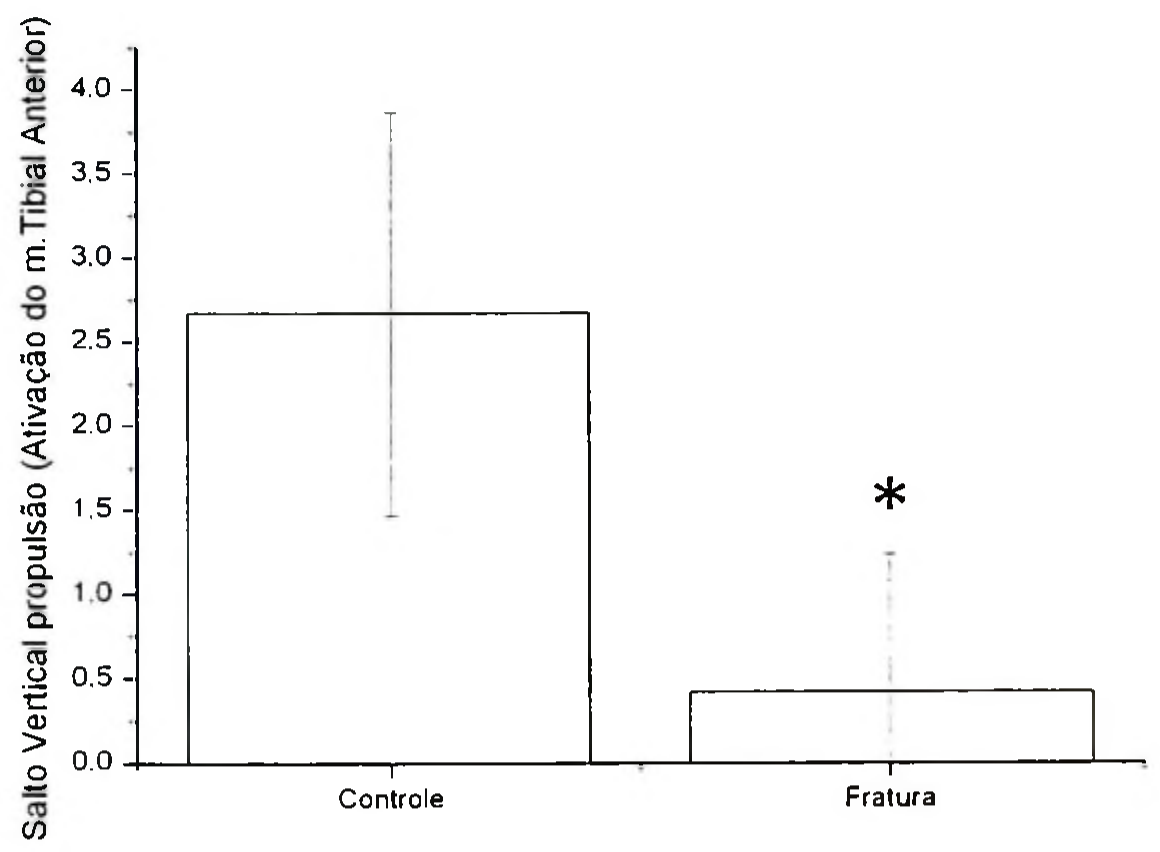

Figura 20-Média e desvio padrão do RMS (u.a.) para o músculo Tibial Anterior (TA) no momento $50 \mathrm{~ms}$ pós-contato de propulsão para o grupo controle e o grupo com histórico de Fratura por Estresse na condição de salto vertical. Onde (") indica diferença significativa $(p \geq 0,05)$ entre os grupos estudados. 


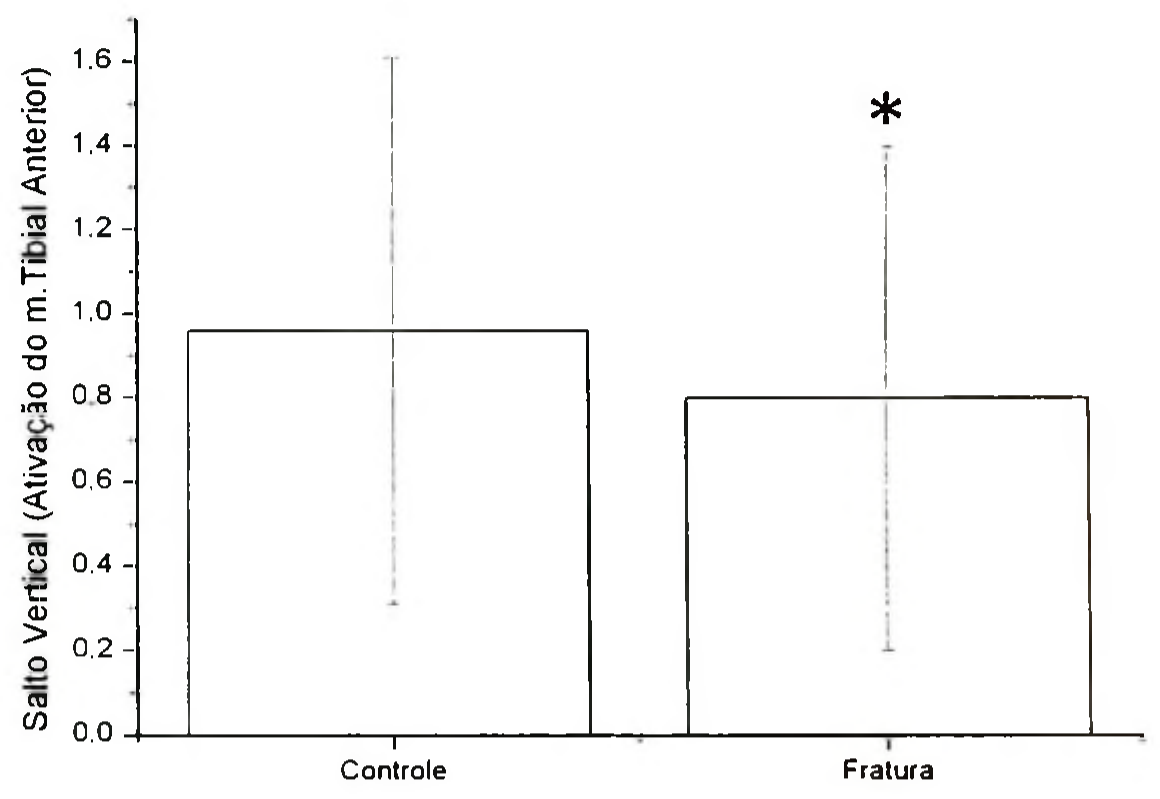

Figura 21 - Média e desvio padrăo do RMS (U.a.) para o músculo Tibial Anterior (TA) no momento $50 \mathrm{~ms}$ pré-contato de aterrissagemo para o grupo controle e o grupo com histórico de Fratura por Estresse na condiçăo de salto vertical. Onde $\left(^{\circ}\right)$ indica diferença significativa $(p \geq 0,05)$ entre os grupos estudados. 


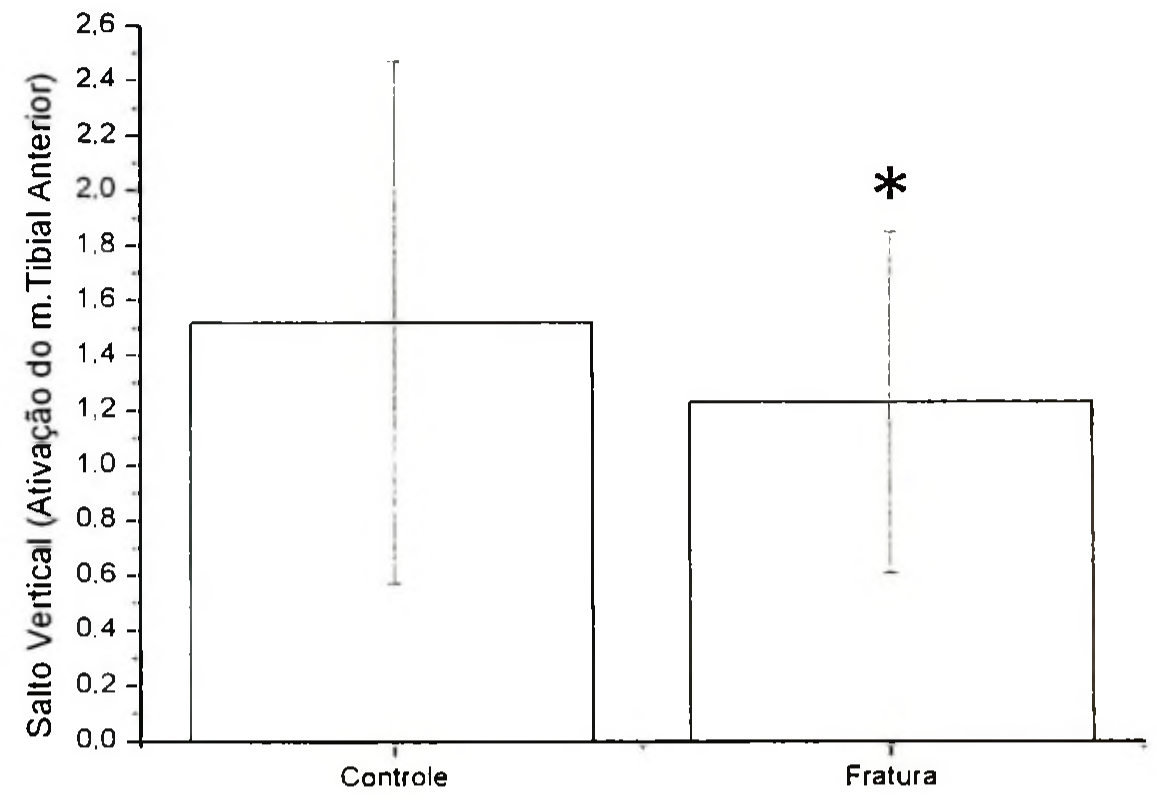

Figura22- Média e desvio padrão do RMS (U.a.) para o músculo Tibial Anterior (TA) no momento $50 \mathrm{~ms}$ pós-contato de aterrissagem para o grupo controle e o grupo com histórico de Fratura por Estresse na condição de salto vertical. Onde (") indica diferença significativa $(p \geq 0,05)$ entre os grupos estudados. 


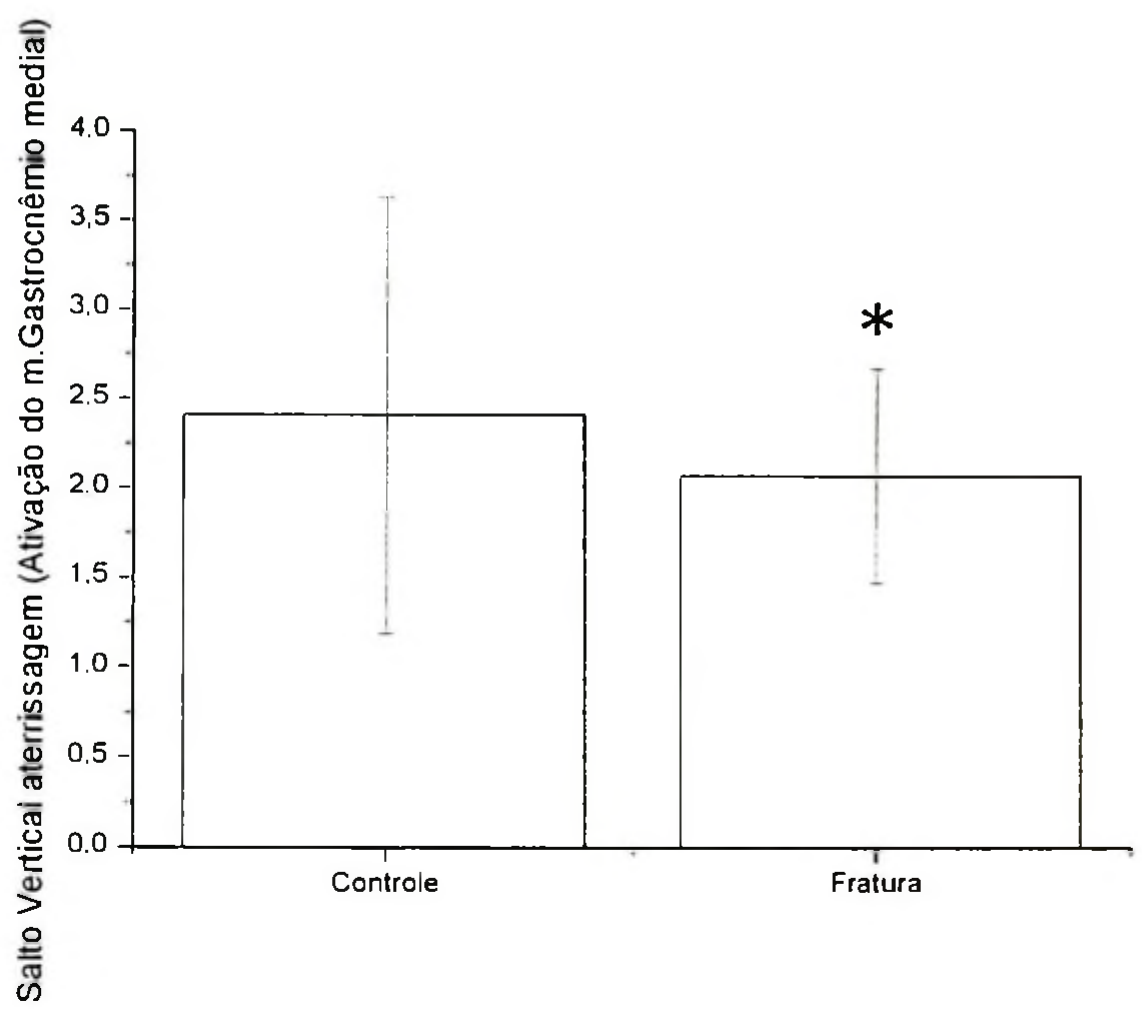

Figura 23- Média e desvio padrāo do RMS (u.a.) para o músculo Gastrocnèmio medial (GM) no momento $50 \mathrm{~ms}$ pós-contato de aterrissagem para o grupo controle e $\circ$ grupo com histórico de Fratura por Estresse na condiçāo de salto vertical. Onde (") indica diferença significativa $(p \geq 0,05)$ entre os grupos estudados. 


\section{DISCUSSÃO}

O objetivo central do estudo foi identificar com analisar o comportamento de paràmetros biomecânicos de atletas com histórico de fraturas por estresse. Tal análise foi fundamentada em aspectos dinâmicos e eletromiográficos mensurados durante a realização de movimentos selecionados de locomoção.

A Força de Reação do Solo foi a variável selecionada para descrever o comportamento dinâmico dos grupos estudados. Parâmetros como o pico da força, o tempo para atingir o pico e o Gradiente de crescimento desta força são apontados como possiveis indicadores das cargas externas impostas ao aparelho locomotor (MUNRO,1987; LIU\&NIGG, 2000; ZADPOOR et al, 2007; ZADPOOR \& NIKOOYAN, 2011).

Em uma meta-análise pautada neste assunto, ZADPOOR \& NIKOOYAN (2011) apontam que uma significativa parcela dos artigos disponiveis na literatura especializada sugere haver diferenças significativas nas variáveis relacionadas à FRS em corredores com histórico de fraturas por estresse quando comparados corredores que nāo apresentavam a referida lesāo. Ainda que os autores relatem năo haver consistência entre os artigos revisados no que se refere as variáveis que sofreram maior influência do histórico de fratura, deve-se considerar que, conforme aponta a literatura, a FRS, variável eleita para indicar o comportamento dinâmico dos grupos estudados, é um importante parâmetro no estudo das sobrecargas mecânicas impostas ao aparelho locomotor pelas cargas externas (MUNRO,1987; LIU\&NIGG, 2000;). Desta forma, parâmetros como o pico da força vertical, o tempo para atingir o pico e o Gradiente de crescimento desta força sảo apontados como possiveis indicadores das cargas externas impostas ao aparelho locomotor. Aproximadamente $46 \%$ dos artigos mostraram não haver diferença significativa entre os grupos (ZADPOOR \& NIKOOYAN, 2011).

Contrariando nossas hipóteses, as alteraçōes dinâmicas observadas em funçāo do histórico de fraturas foram observadas em algumas poucas situaçōes.

Os saltos especificos (ataque, bandeja, bloqueio, rebote), que foram aqueles que geraram as maiores cargas externas, nảo houve diferença significativa entre os grupos quando da análise das variáveis referentes à intensidade da força e seus respectivos tempos de duração. A auséncia de diferenças entre os grupos 
observados ocorreu tanto nas fases de propulsão como nas fases de aterrissagem dos referidos movimentos, entretanto, nos saltos verticais não específicos, o impulso de aterrissagem do grupo controle e do grupo experimental foram diferentes. Situação semelhante ocorreu nos saltos verticais.

A ausência de alterações substanciais também foi observada quando da análise do deslocamento lateral. Nesta condição, embora o tempo para atingir o pico da força vertical tenha sido maior no grupo experimental, a magnitude do pico e o GC não foram diferentes entre os grupos. Considerando que tais variáveis estão diretamente associadas às cargas externas transferidas ao aparelho locomotor, pode-se afirmar que o grupo experimental não apresentou condições mecânicas que justificassem -a priori- o surgimento de fratura por estresse.

Porém, para a condição de deslocamento anterior, observou-se uma diferença significativa entre os grupos para as variáveis temporais. No grupo experimental o tempo para atingir o pico da força vertical foi significativamente menor, situação que condicionou um também significativo aumento do GC, em relação ao grupo controle. O presente fato torna-se importante uma vez que caracteriza que o grupo experimental, embora tenha recebido um pico de força semelhante ao grupo controle, sofreu um crescimento desse pico de forma mais abrupta, condição que pode sinalizar um aumento da sobrecarga mecânica induzida pelas forças externas.

Considerando ser o deslocamento anterior o movimento que se mostrou mais sensivel à influência do histórico de fratura, torna-se importante destacar o comportamento muscular nesta condição, tendo-se em vista que o mesmo pode ter influenciado diretamente o observado comportamento dinàmico. Ao se avaliar, por intermédio do RMS, a intensidade da ação muscular, observou-se um comportamento bastante interessante. Pode-se observar que a atividade muscular do gastrocnemio medial na fase de pré-contato foi significativamente maior $(10 \%)$ no grupo experimental quando comparado ao grupo controle. Por além das relatadas diferenças no nivel de ativação muscular, outro aspecto que merece destaque diz respeito ao fato de esse ter sido a única situação onde a ativação do tibial anterior se mostrou menor do que a observada para o gastrocnemio medial. Deve apontar que, para o grupo controle, tanto na condiçảo précomo na condição de pós-contato, a ativação do tibial anterior foi menor do a observada para o gastrocnemio medial.

O comportamento observado muscular observado no controle é típico dessa 
condição de movimento. Segundo CAVANAGH (1990) a alta atividade do músculo tibial anterior se dá pelo fato de esse músculo estar se preparando para auxiliar no controle das cargas mecânicas geradas pelo movimento. Durante uma corrida rápida, a ação antecipatória do tibial anterior, que objetiva preparar a articulação do tornozelo e o membro inferior para receber o choque mecânico derivado do contato com o solo, inicia-se cerca de $50 \mathrm{~ms}$ antes deste primeiro contato.

Uma situação de falha do músculo tibial anterior como a ocorrida na fadiga, ocorre o aumenta a velocidade de choque da tíbia com o solo, diminui o tempo para o pico e aumenta o GC da força vertical, e ainda pode levar a um estiramento ósseo na região anterior da tíbia, fatores esses que podem estar intimamente ligados ao surgimento de uma fratura por estresse (MILGROM, 1985; YOSHIKAWA, 1994; MIZRAHI, 2000; JAMES,2006; MILGROM, 2007; MILNER, 2007;.

Um outro fato a ser considerado, é que, cargas mecânicas aplicadas em alta freqüência tendem a ser mais prejudiciais ao tecido ósseo do que cargas aplicadas em baixas frequências. Em um estudo realizado com corredores, MILNER (2007) evidencia que o grupo com histórico de fratura apresentou maior GC da força vertical de reação do solo mesmo não sendo exposto à fadiga. Para o autor a o movimento conjunto das articulações do membro inferior pode ter contribuido para esse comportamento. Nesse estudo, embora a correlação da diminuição de flexão do joelho no grupo com fratura tenha sido média, a mesma correlação no grupo controle foi baixa. Esse grau de correlação, segundo o autor, aumenta conforme o sujeito vai entrando em fadiga e diminui a flexão do joelho, fato que pode fazer com que, sujeitos que já apresentaram fraturas por estresse cheguem a um grau de correlação alto antes de sujeitos que nunca apresentaram essa patologia.

Os resultados encontrados no presente trabalho condizem com uma condiçāo de nāo fadiga e foram coletados em voluntárias em fase inicial de treinamento. Essas condiçōes não nos permitem afirmar que as alterações aqui encontradas possam sofrer alteraçōes sob efeito de esforço físico, fadiga ou ainda diferentes fases da temporada de treinamento.

Encontrados na literatura apenas os estudos de GRIMSTON et al. (1991) e MILNER (2007) a respeito da influência de alteraçðes no recrutamento muscular dos músculos do membro inferior no comportamento de variáveis dinâmicas, exceção feita à situações onde os sujeitos avaliados encontravam-se em condiçăo de fadiga. Nas demais condiçōes até então citadas nesse trabalho, a literatura evidencia que a 
incapacidade do tibial anterior em função da indução da fadiga muscular localizada está relacionada ao aumento da sobrecarga mecânica imposta ao aparelho locomotor. Considerando ser a fadiga um processo que afeta o recrutamento muscular, tal como observado para os voluntarios com histórico de fratura por estresse, poderiamos hipotetizar que a predisposição ao aumento da sobrecarga mecânica, ocorrida em situação de fadiga, também poderia ocorrer para os sujeitos com histórico de fratua por estresse., Esse fato destaca a importância da alteração encontrada nas características do sinal eletromiográfico do grupo experimental e sua associação com o aumento do GC da força nesse mesmo grupo

A redução na ativação do tibial como umas possiveis causas das alteraçōes dinâmicas observadas nos sujeitos com histórico de fratura por estresse pode ter origem no quadro de dor decorrente da lesão. A literatura evidencia que a dor pode levar a uma considerável diminuiçăo dos impulsos neuromusculares transmitidos para as unidades motoras (ASHTON-MILLER,1990; SOHN,2000; SCHULTE, 2004; ERVILHA, 2004), que por sua vez podem condicionar alteração na estratégia de ativação muscular (GRAVEN-NIELSEN, 1997) gerando diferença distribuição da carga mecânica (ERVILHA, 2005). Sendo assim, uma vez sofrida uma sobrecarga que gere degeneração tecidual e dor, as alterações musculares subsequentes precisam ser investigadas na tentativa de evitarem-se as recidivas da lesảo.

Tal condiçāo nāo deve ter sido observada em todos os tipos de movimento em função das características mecânicas que os distinguem. Nas condiçōes observadas nos saltos específicos, o regime de ativação muscular apresentado pelo é compativel com o descrito na literatura. Nos saltos verticais descritos, tanto no momento de propulsão quanto no momento de aterrissagem, o músculo responsável pelo movimento seria o gastrocnemio (KYROLÄINEN, 2003), e este não apresentou diferença estatisticamente significativa entre os grupos estudados.

Tais alteraçōes no equilibrio de ação entre o tibial anterior e o gastrocnemio poderiam afetar o equilíbrio mecânico da articulação do tornozelo aumentando a tendência de extensão e diminuindo a tendência de flexão distribuição de forças na estrutura óssea (MIZRAHI, 2000). Dados complementares são necessários para melhor avaliar esta hipótese.

Dados complementares também são necessários para um melhor entendimento das alterações pontuais encontradas nos resultados que não seguiram um padrão especifico, como as encontradas durante a realização do bloqueio e do 
rebote. Nessa condiçăo de salto vertical específico do esporte, observou-se uma diminuição ( $36 \%$ ) do valor RMS apenas nos $50 \mathrm{~ms}$ que antecederam o início da fase concêntrica durante a impulsảo, no grupo experimental, já no salto vertical não específico o valor RMS do músculo tibial no grupo experimental foi menor em todos os janelamentos estudados. Observa-se, portanto, que as alterações ocorridas foram movimento dependente e năo fratura dependente.

De um modo geral, pode-se observar que as diferenças encontradas entre o grupo experimental e o grupo controle nas condições de deslocamento ànteroposterior foram as que mais se caracterizaram com padrões musculares descritos na literatura e relacionados com a fratura por estresse. Nas demais condições, observou-se que as variações musculares estāo mais relacionadas com as caracteristicas de movimento do que com o mecanismo de fratura. 


\section{CONCLUSĀO}

Os resultados obtidos evidenciam a existência de importantes alteraçōes no acionamento muscular e nas respostas dinâmicas das voluntárias com histórico de fratura por estresse. Dentre as principais conclusōes destacamos:

a) As alteraçōes musculares encontradas podem explicar as alteraçōes no comportamento dinàmico de atletas que apresentaram algum episódio de fratura por estresse;

b) As alterações musculares entre tibial anterior e gastrocnêmio medial afetam principalmente o comportamento dinâmico dos deslocamentos com mudanças bruscas de direção, exercendo maior influência nos deslocamentos com mudanças ântero-posteriores;

c) As alteraçōes musculares parecem năo exercer tanta influência nas condiçōes de salto;

d) Das variáveis dinâmicas avaliadas, a variável tempo e a variável gradiente de crescimento apresentaram as maiores variaçōes

e) A alteração no padrão de recrutamento muscular pode ser um fator interessante a ser avaliado nas condiçōes de locomoção onde atletas apresentam uma capacidade de controle de carga ineficaz. 


\section{REFERÉNCIAS BIBLIOGRÁFICAS}

ACIERNO, S.P.; BARATTA, R.V.; SOLOMONOW, M. A practical guide to electromyography for biomechanists, New Orleans, Louisiana State University, 1995.

AMADIO, A. (1989). Fundamentos da Biomecânica do Esporte. Consideraçōes sobre a Análise Cinética e Aspectos Neuro-musculares do Movimento. Tese de Doutoramento. Escola de Educação Fisica da Universidade de São Paulo. Nāo Publicado.

AMADIO, A.C.; DUARTE, M. Fundamentos biomecânicos para análise do movimento humano. Săo Paulo: Laboratório de Biomecânica/EEFEUSP, 1998.

AMADIO, A.C.; Esporte e Atividade Fisica. Interaçăo entre Rendimento e Qualidade de Vida. 1a ed., pp 27-50, 2002.

AOKI, Y.; YASUDA, $K$;; TOHYAMA, H. Magnetic resonance imaging in stress fractures and shin splints. Clin Orthop Relat Res. 421: 260-267. 2004.

ARAÚJO, R.C.: Utilização da Eletromiografia na Análise Biomecânica do Movimento Humano, 1998, 151p. Tese (Doutorado) - Escola de Educaçăo Fisica e Esporte, Universidade de Săo Paulo, Săo Paulo, 1998.

Ashton-Miller JA, McGlashen KM, Herzenberg JE, Stohler CS. Cervical muscle myoelectric response to acute experimental sternocleidomastoid pain.Spine 
(Phila Pa 1976). 1990 Oct;15(10):1006-12.

BARFIELD, W. R.; OTTENI, J. F.; MCBRYDE, A. M.; CARTER, J. S.; NIETERT, P. J. Longitudinal Study Of Factors Affcting Stress Fracture Risk In Two Distinct College Female Populations. Journal of Exercise and Sport Sciences - Vol. 1, N.o 1 - Jan./Jul., 2005.

BERGMANN, G., ROHLMANN, A.; GRAICHEN, F. Hip joint loading during going up- and downstairs. Trans. Eur. orthop. Res. Soc. 8, 8. 1991.

BODEN, B. P.; OSBAHR, D. C. High-risk stress fractures: evaluation and treatment. J Am Acad Orthop Surg. Nov-Dec;8(6):344-53, 2000.

BODEN, B. P.; OSBAHR, D. C.; JIMENEZ C. Low-risk stress fractures. Am J Sports Med. Jan-Feb;29(1):100-11, 2001.

CAVANAGH, P.R.; LAFORTUNE, M.A. Ground reaction forces in distance running. Journal of Biomechanics, v.13, n.5, p.397-406, 1980.

CLARYS, J.P.P.; LEWILLI, L. Clinical and kinesiological electromyography by "Le Dr. Duchenne (De Boulogne)". In: CAPAZZO, A.; MERCHETTI, M.; TOSI, COHEN M \& ABDALA R.J. Lesōes nos Esportes: diagnóstico - prevenção tratamento. Rio de Janiero: Revinter, $937 \mathrm{p}$.

DAINTY, D.A.; Standardizing Biomechanical Testing in Sport, Champaing, Human Kinetics, 145p, 1987. 
DE LUCA, C.J. The Use of Surface Electromyography in Biomechanics. Journal of Applied Biomechanics, Vol 13, pp 135-63, 1993.

DE LUCA, C.J.; MERLETTI, R. Surface EMG Crosstalk Among Muscles of the Leg. Electroencephalography and Clinical Neurophysiology Vol 69, pp 56875,1988 .

DE LUCA, G. Fundamental Concepts in EMG Signal Acquisitions. Delsys Incorporated, Revista 2.1, Março, pp.12-19, 2003.

DEVAS M.B. Stress fracture of the tibia in athletes or shin soreness. J Bone Joint Surg Am; 40B:227-2, 1958.

EKENMAN, I; TSAI-FELLANDER,L; WESTBLAD, P. A study of intrinsic factors in patients with stress fractures of the tibia. Foot Ankle Int. 17(8):477-82, 1996.

ERVILHA, U.F.; ARENDT-NIELSEN, L.; DUARTE, M.; GRAVEN-NIELSEN, T.Effect of load level and muscle pain intensity on the motor control of elbow-flexion movements. Eur J Appl Physiol. 2004 Jun;92(1-2):168-75. Epub Mar 26, 2004.

ERVILHA, U.F.; FARINA, D.; ARENDT-NIELSEN, L.; GRAVEN-NIELSEN T.Experimental muscle pain changes motor control strategies in dynamic contractions.Exp Brain Res.Jul; 164(2):215-24. Epub 2005 Jun 11, 2005. 
FREDERICSON, M.; JENNINGS, F.; BEAULIEU, C.; MATHESON, G.O. Stress fractures in athletes. Topics in Magnetic Resonance Imaging, 17(5), 309-325, 2006.

FUKADA, E.; YASUDA, I. On the piezoelectric effect of bone. J Phys Soc Japan, 12:1158-62, 1957.

GAETA,M; MINUTOLI, F; SCRIBANO,E. CT and MR Imaging Findings in Athletes with Early Tibial Stress Injuries:Comparison with Bone Scintigraphy Findings and Emphasis on Cortical Abnormalities. Radiology. 235, 553-561, 2005.

GALBRAITH, R.M.; LAVALLEE, M.E. Medial tibial stress syndrome: conservative treatment options. Curr Rev Musculoskelet Med 2(3):127, 2009.

GARDNER,L; DZIADOS,J; JONES,B. Prevention of Lower Extremity Stress Fractures: A Controlled Trial of a Shock Absorbent Insole. AJPH 78(12), 1988.

GRAVEN-NIELSEN, T.; SVENSSON, P.; ARENDT-NIELSEN, L. Effects of experimental muscle pain on muscle activity and co-ordination during static and dynamic motor function.Electroencephalogr Clin Neurophysiol. Apr;105(2):156-64, 1997.

GREANEY, R. B., GERBER, F. H., LAUGHLIN, R. L., KMET, J. P., METZ, C. D., KILCHENSKI, T. S., RAO, B. R. ANDSILVERMAN, E. D. Distribution and natural history of stress fracture in U.S.Marine recruits. Radiology146, 339-346, 1983. 
HENNIG, E.M.; VALIANT, G.A.; LIU, Q. Biomechanical variables and the perception of cushioning for running in various types of footwear. Journal of Applied Biomechanics, Champaign, v. 12, p.143-150, 1996.

HODGES PW, RICHARDSON CA . Altered trunk muscle recruitment in people with low back pain with upper limb movement at different speeds. Arch Phys Med Rehabil. Sep;80(9):1005-12, 1999.

ISAKOV, E.; MIZRAHI, J.; SOLZI, P.; SUSAK, Z.; LOTEM, M. Response of the peroneal muscles to sudden inversion of the ankle during standing. Int $\mathrm{J}$ Sports Biomec. 2: 100-102. 1986

ISAKOV, E.; MIZRAHI, J.; SOLZI, P.; SUSAK, Z.; LOTEM, M. Response of the peroneal muscles to sudden inversion of the ankle during standing. Int $J$ Sports Biomec. 2: 100-102. 1986

IWAMOTO, J.:TAKEDA, T. - Stress fractures in athletes: review of 196 cases. J Orthop Sci.;8(3):273-8, 2003.

JAMES CR, DUFEK JS, BATES BT. Effects of stretch shortening cycle exercise fatigue on stress fracture injury risk during landing. Res Q Exerc Sport. 2006 Mar;77(1):1-13.

KEMPFER, G; FIGUEIREDO, A; MACEDO,S. Fratura de estresse e a medicina nuclear. 10 (6), 2004.

KORPELAINEN, R.; ORAVA, S.; KARPAKKA, J.; SIIRA, P.; HULKKO, A. 
Risk Factors for Recurrent Stress Fractures in Athletes Am J Sports Med 29: 304, 2001.

KYROLÄINEN H, FINNI T, AVELA J, KOMI PV.Neuromuscular behaviour of the triceps surae muscle-tendon complex during running and jumping. Int $\mathrm{J}$ Sports Med. Apr;24(3):153-5, 2003.

LAKE, M.J.; LAFORTUNE, M.A. Mechanical inputs related to perception of lower extremity impact loading severity. Medicine and Science in Sports and Exercise, Madison, v.30, n.1, p.136-143, 1998.

LIRANI, A. R., LAZARETTI-CASTRO M. Evidèncias da Ação de Agentes Fisicos Sobre o Metabolismo do Tecido Ósseo e Seus Potenciais Usos Clinicos. Arq. Bras. Endocrinol. Metab. v. 49, n. 6, Dez. 2005. Disponivel em: http://www.scielo.br/pdf/abem/v49n6/27388.pdf. Acesso em: 28 jul, 2007.

LIU, W.; NIGG, B.M. A mechanical model to determine the influence of masses and mass distribution on the impact force during running. Journal of Biomechanics 33 (2), 219-224, 2000.

MATHESON, G. O.; CLEMENT, D.B.; MCKENZIE, D.C.; TAUTON, J.E.; LLOYD-SMITH D.R.; MACINTYRE, J.G. Stress fractures in athletes. A study of 320 cases. Am J Sports Med. 1987 Jan-Feb;15(1):46-58.

MCMAHON, T. Muscles, Reflexes and Locomotion. Princeton: University Press, 1984. 
MILANI, T.L.; HENNIG, E.M., LAFORTUNE, M.A. Perceptual and biomechanical variables for running in identical shoe constructions with varying midsole hardness. Clinical Biomechanics, v.12, n.5, p.294-300, 1997.

MILGROM C, FINESTONE A, SIMKIN A, EKENMAN I, MENDELSON $S$, MILLGRAM M, NYSKA M, LARSSON E, BURR D. In-vivo strain measurements to evaluate the strengthening potential of exercises on the tibial bone. $J$ Bone Joint Surg Br. May;82(4):591-4, 2000.

MILGROM et al. The effect of muscle fatigue on in vivo tibial strains. J Biomech.40(4):845-50, 2007.

MILGROM, C., GIALADI, M., STEIN, M., KASHTAN, H., MARGULIES, J., CHISIN, R., STEINBERG, R., AHARONSON, Z.,. Stress fractures in military recruits. A prospective study showing an unusually high incidence. Journal of Bone and Joint Surgery 67B, 732-735 1985.

MILLER, D. Ground reaction forces in distance running. In: CAVANAGH, P.R., ed. Biomechanics of distance running. Champaign, Human Kinetics, 1990.

MIZRAHI J.; VERBITSKY, O. and ISAKOV, E. Fatigue-Related Loading Imbalance on the Shank in Running: A Possible Factor in Stress Fractures . Annals of Biomedical Engineering, 28: 463 - 469, 2000.

MOEN, M. H.; BONGERS, T.; BAKKER, E. W.; ZIMMERMANN, W. O.; WEIR, A.; TOL, J. L.; BACKX, F. J. G. Risk factors and prognostic indicators for medial tibial stress syndrome.Scand J Med Sci Sports 2010. 
MONTELEONE GP JR. Stress fractures in the athlete. Orthop Clin North Am. Jul;26(3):423-32, 1995.

MUNRO, C.F.; MILLER, D.I.; FUGLEVAND, A.J. Ground reaction forces in running: a reexamination. Journal of Biomechanics 20 (2), 147-155, 1987.

NIGG, B.M.; SEGESSER, B.The running shoe--a means of preventing running complaints Z Orthop Ihre Grenzgeb. Nov-Dec;124(6):765-71, 1986.

NORDIN, M.; FRANKEL, V. Biomecânica Básica do Sistema Musculoesquelético.3ed. Ed Guanabara, 2003.

NOVACHECK TF.The biomechanics of running. Gait Posture. Jan 1;7(1):77951998.

PAUL, I. L., MUNRO, M. B., ABERNETHY, P. J., SIMON, S. R., RADIN, E. L. AND ROSE, R. M. Musculo-skeletal shock absorption: relative contribution of bone and soft tissues at various frequencies. J. Biomech. 11, 237-239. 1978.

PAUWELS, F.. Contributions on the Functional Anatomy of the Locomotor Apparatus. Biomechanics of the Locomotor Apparatus. Berlin: Springer-Verlag. 1980.

ROMANI,W; GIECK, J; PERRIN, D. Mechanisms and management of stress 
fracture in physically active person. Journal of Athletic Training 37:306-314, 2002.

RUBIN, C. T., HARRIS, M. C. A., JONES, B. H., ERNST, H. B. ANDLANYON, L. E. Stress fractures: the remodeling response to excessive repetitive loading. Trans. orthop. Res. Soc.9, 303, 1984.

SCHULTE, E.; CIUBOTARIU, A.; ARENDT-NIELSEN, L.; DISSELHORST-KLUG, C.; RAU, G.; GRAVEN-NIELSEN, T.Experimental muscle pain increases trapezius muscle activity during sustained isometric contractions of arm muscles. Clin Neurophysiol. Aug;115(8):1767-78, 2004.

SENIAM (2006). Surface Electroyography for the Non-Invasive Assessment of Muscles. Internet Source: http://www. seniam.org. 22 May 2006.

SERRĀO, J.C. Aspectos biomecânicos da influência do calçado esportivo na locomoção humana. 192f. Tese (Doutorado) - Escola de Educação Fisica, Universidade de São Paulo, São Paulo. 1999.

SMITH, D. J.; ROBERTS, D.; WATSON, B. Physical, physiological and performance differences between Canadian national team and universiade volleyball players. Journal of Sports Sciences, London, v. 10, p. 131-138, 1992.

SOHN MK, GRAVEN-NIELSEN T, ARENDT-NIELSEN L, SVENSSON P.Inhibition of motor unit firing during experimental muscle pain in humans. Muscle Nerve. Aug;23(8):1219-26, 2000. 
STEINEGGER T, WIEDERKEHR M, LUDIN HP, ROTH F. Electromyography as a diagnostic aid in tetanus Schweiz Med Wochenschr. 1996 Mar 9;126(10):37985.

TIETZ,C.C. Patellofemoral pain in Dancers. J Operd May/Jun;34-36,1987.

TOMMAZINI, S.;NASSER,P.; SCHAFFLER, M. Relationship between bone morphology and bone quality in male tibias: implications for stress fracture risk. $J$ Bon Min Res. 20: 1372-1380.2005.

WARDEN S. J.; BURR, D. B.; BRUKNER, P. D.;Stress Fractures: Pathophysiology, Epidemiology, and Risk Factors. Current Osteoporosis Reports, 4:103-109, 2006.

WINTER, D.A. Biomechanics and Motor Control of Human Movement. $2^{\mathrm{a}}$ ed., New York, pp 14-16, 1990.

WINTER, D.A., BISHOP, P.J. Lower extremity injury - Biomechanical factors associated with chronic injury to the lower extremity. Sports Med. Sep;14(3):149-56, 1992.

YOSHIKAWA, T.; The effects of muscle fatigue on bone strain - J. exp. Biol. $188,217-233,1994$.

ZADPOOR, A. A, NIKOOYAN, A. A. The relationship between lower- 
extremity stress fractures and the ground reaction force: A systematic review Clinical Biomechanics 26 (2011) 23-28.

ZADPOOR, A.A.; NIKOOYAN, A.A.; ARSHI, A.R. A model-based parametric study of impact force during running. Journal of Biomechanics, 40 (9), 2012-2021, 2007. 


\section{ANEXOS}

\section{Consentimento informado em participacăo da pesquisa.}

Projeto de Pesquisa:

Fratura por Estresse de Tibia: Variáveis biomecânicas do salto vertical e deslocamentos em solo em atletas saltadores de alto rendimento.

Responsáveis: Fábio Rodrigues José e Prof. Dr. Júlio Cerca Serrão.

O presente projeto de pesquisa tem como propósito verificar as variáveis biomecânicas do salto vertical e corrida em atletas saltadores com quadro de fratura por estresse de tibia. Para tanto, propomos a realização de três condições experimentais.

Na Condição experimental 1, o voluntário deverá saltar sobre uma plataforma de força fixa ao solo por cinco vezes.

Na Condiçāo experimental 2 , o voluntário deverá realizar uma mudança rápida de direção (corrida de frente mudando rápidamente para corrida de costas) sendo que o ponto de transição foi sobre uma plataforma de força fixa ao solo. Foram realizadas cinco mudanças com cada membro por cinco vezes.

Na Condição experimental 3, o voluntário deverá realizar uma mudança rápida de direçāo (deslocamento lateral direito ou esquerdo, mudando rápidamente para deslocamento em sentido oposto) sendo que o ponto de transição foi sobre uma plataforma de força fixa ao solo. Foram realizadas cinco mudanças com cada membro por cinco vezes.

- Destacamos que todos os experimentos foram monitorados por eletromiografia e cinemetria, instrumentos esses de aplicação não invasiva. Duante o experimento o laboratório estará equipado com material e profissionais treinados para o pronto atendimento de eventuais intercorrências sofridas pelo sujeito.

Após o conhecimento do experimento, concordo em participar deste projeto de pesquisa, na condição de voluntário. Declaro estar ciente de todos 
os benefícios e maleficios que o experimento pode me causar, declaro ainda que posso abandonar, sem nenhum prejuizo, o experimento em qualquer etapa do seu desenvolvimento.

RG.:

Data:

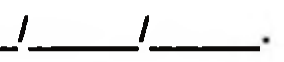

Assinatura do voluntário: 